Working Paper/Document de travail 2013-2

\title{
House Prices, Consumption and the Role of Non-Mortgage Debt
}

by Katya Kartashova and Ben Tomlin 
Bank of Canada Working Paper 2013-2

January 2013

\title{
House Prices, Consumption and the Role of Non-Mortgage Debt
}

\author{
by \\ Katya Kartashova and Ben Tomlin \\ Canadian Economic Analysis Department \\ Bank of Canada \\ Ottawa, Ontario, Canada K1A 0G9 \\ kkartashova@bankofcanada.ca \\ btomlin@bankofcanada.ca
}

Bank of Canada working papers are theoretical or empirical works-in-progress on subjects in economics and finance. The views expressed in this paper are those of the authors.

No responsibility for them should be attributed to the Bank of Canada. 


\section{Acknowledgements}

We are grateful to Jeannine Bailliu, Paul Beaudry, Shutao Cao, Allan Crawford, Paul Gilbert, Haifang Huang, Maral Kichian, Cesaire Meh, Gregor Smith, and Alexander Ueberfeldt for their comments and advice. We would also like to thank Carl Black for his excellent research assistance. Any errors and omissions are solely the responsibility of the authors. 


\begin{abstract}
This paper examines the relationship between house prices and consumption, through the use of debt. Using unique Canadian household-level data that reports the uses of debt, we begin by looking at the relationship between house prices and debt. Using quantile regression, we find a positive and significant relationship between regional house prices and total household debt all along the conditional debt distribution. This suggests that the household-level relationship between house prices and debt goes beyond the purchase of real estate. We then find a positive relationship between house prices and non-mortgage debt (the sum of secured lines of credit, unsecured lines of credit, leases and other consumer loans, except for credit cards) for homeowners. Combining these results with the reported uses of non-mortgage debt allows us to connect house prices and nonhousing consumption - this connection is new to the literature on house prices and consumption. We conclude that the increases in house prices over the 1999-2007 period were, indeed, associated with an increase in non-mortgage debt and non-housing consumption. Our results can be thought of as the establishment of a conservative lower bound for the overall relationship between house prices and aggregate consumption.
\end{abstract}

JEL classification: E21, D10, D14, D31

Bank classification: Credit and credit aggregates; Domestic demand and components

\title{
Résumé
}

La présente étude porte sur le lien que le recours au crédit pourrait constituer entre les prix des maisons et la consommation. À partir d'un ensemble unique de données détaillées sur les ménages canadiens qui rend compte de l'utilisation que ceux-ci font de leurs emprunts, les auteurs examinent tout d'abord le lien entre les prix des maisons et la dette. Une régression quantile leur permet d'observer une relation positive et significative entre les prix régionaux des maisons et la dette totale des ménages pour toute la distribution conditionnelle des emprunts de ces derniers. Ce résultat donne à penser que le rapport à l'échelon des ménages entre les prix des maisons et l'endettement ne se limite pas à l'achat de biens immobiliers. Les auteurs mettent ensuite en évidence un lien positif entre les prix des maisons et la dette non hypothécaire (laquelle regroupe les lignes de crédit garanties, les lignes de crédit non garanties, le crédit-bail et les autres prêts à la consommation, mais exclut les cartes de crédit) chez les propriétaires de logements. Le rapprochement de ces résultats et des données sur l'utilisation des crédits non hypothécaires leur permet d'établir une relation entre les prix des maisons et la consommation - lien inédit dans la littérature traitant de ces deux éléments. Les auteurs concluent que la hausse des prix des maisons au cours de la période allant de 1999 à 2007 a effectivement été associée à un accroissement de la dette non hypothécaire et de la consommation hors logement. Ils estiment aussi que les résultats de leurs calculs peuvent être considérés raisonnablement comme des valeurs seuils dans la relation globale qui existe entre les prix des maisons et la consommation totale.

Classification JEL : E21, D10, D14, D31

Classification de la Banque : Crédit et agrégats du crédit; Demande intérieure et composantes 


\section{Introduction}

In the last two decades, many developed countries experienced prolonged increases in house prices and household debt. In Canada, household debt has been growing due to net increases in homepurchase mortgages and in mortgage refinancing, as well as an increase in non-mortgage debt, both secured and unsecured by housing. Accompanied by rising house prices, these debt increases have been reflected in aggregate real and financial flows, including consumption, new housing construction, home renovations, and net acquisition of financial assets. While debt and house prices continue to rise in Canada, some of the countries that experienced these concurrent increases in the past have since seen their reversals, and the decline in house prices and continued household deleveraging have brought with them a host of negative influences for these economies. Understanding the links between house prices, debt and other real and financial variables, both in "good" and "bad" times, is therefore important.

Within this context, the goal of this paper is to establish a relationship between house prices and total household debt, and between its non-mortgage component (the sum of secured lines of credit, unsecured lines of credit, leases and other consumer loans, except for credit cards) and consumption. ${ }^{1}$ Our definition of non-mortgage debt can also be called consumer credit minus credit card balances. The importance of questions regarding the drivers of household debt and the effect of debt on economic activity has been highlighted by a number of other recent research projects at the Bank of Canada, such as Bailliu, Kartashova and Meh (BKM, 2012) and Crawford and Faruqui (2012). In particular, BKM study the link between household debt and consumption, focusing on home-equity extraction, a large part of which is constituted by changes in mortgage debt - either due to net mortgage refinancing or changes in mortgage debt associated with changes in ownership of existing homes (see BKM for more detailed definitions) - but also include home-equity lines of credit, which are usually classified as part of consumer debt. Unlike this paper, however, BKM do not establish or measure the link between house prices and debt, and provide only indirect evidence. Crawford and Faruqui examine some of the reasons for the expansion in Canadian household credit and point to higher house prices as one of the factors. Despite links between the questions, the

\footnotetext{
${ }^{1}$ In addition to consumption, uses of debt are also related to portfolio re-balancing (including changing the asset mix and re-optimizing the debt structure of households), which we discuss in the overview of price effects section, but do not report any quantitative results.
} 
approaches used in the three papers (BKM, Crawford and Faruqui, and this paper) are different. Therefore, while the broad messages of the importance of household debt and its role in economic activity are similar, the particulars of the approaches and data calculations - including the reporting of summary statistics - should not be directly compared.

Using Canadian household data, we first estimate the relationship between total household debt and house prices. The results of this estimation are used to distinguish between different channels through which household debt is related to house prices. At the household level, this relationship is likely dominated by the link between house prices and the home purchase mortgage component of household debt. Next, we focus on the non-mortgage component of household debt-which can be directly used for a number of purposes other than the purchase of a home ${ }^{2}$ - and establish its relationship with house prices. These last results are then combined with information on the purposes of household debt and the magnitude of house price increases over the 1999-2007 period in order to measure the size of non-mortgage debt flows that were associated with house price increases, and linked to personal consumption expenditures.

There are several channels through which household debt is associated with house price increases. Most notably, higher house prices are linked to increases in mortgage debt, which includes not only balances incurred for the purchase of new and existing homes, but also refinancing of mortgage balances already outstanding at higher amounts. While refinancing does not involve the purchase of a home directly, it can be treated as a repurchase with a loan-to-value (LTV) ratio that is the same or higher than the original. ${ }^{3}$ House price increases are also linked to higher home equity debt, in the form of home equity lines of credit (HELOCs) and home equity loans (HELs), as households may borrow against increases in their home equity due to higher house prices. Finally, unsecured debt can be associated with house prices through wealth effects and credit constraints.

In turn, these sources of debt accumulation are linked to different real and financial flows in the economy. Home purchase mortgages - either for first-time homebuyers or existing homeowners who adjust their housing by trading up or down - can be thought of as primarily financing future

\footnotetext{
${ }^{2}$ In talking about the purposes of debt, one must acknowledge the issue of fungibility of resources. The debt we associate with the purchase of a home, for example, can also be used indirectly to finance other purposes through changes in the down payment amount. The same issue applies to other types of debt, but it can be less important.

${ }^{3}$ While the mortgage balance outstanding against the home increases, its price may also have gone up compared to the date of the original purchase. Depending on the relative magnitude of these increases, the new loan-to-value ratio on the home may increase or remain the same.
} 
housing services consumption. In the case of mortgage refinancing and other forms of home equity debt, housing consumption remains largely unchanged since this debt is not associated with moving from renting to home owning or moving between homes. ${ }^{4}$ This type of debt can be used to finance non-housing consumption and other investment decisions. ${ }^{5}$

This paper is related to the vast literature trying to establish a link between house prices and consumption, including Campbell and Cocco (2007) and Attanasio et al (2009) for the UK, and Bostic, Gabriel and Painter (2009) for the US, to name a few. More directly, this paper fits into a narrower strand of literature that has focused on debt as an intermediary between increases in housing equity due to higher house prices and the uses of this equity (which are either directly or indirectly inferred), including consumption and portfolio rebalancing. This is the approach taken in Mian and Sufi (2009). They use U.S. microdata to examine the association between house prices and household debt, and then the real uses of debt, such as consumption, home renovation, and the purchase of other residences/businesses. They conclude that the rapid increase in house prices likely influenced real expenditure growth at the household level through the use of debt. Dynan and Kohn (2007) study the factors behind household debt increases in the US, including house prices. Greenspan and Kennedy (2008) only link the home-secured component of debt to consumption, assuming the link between house prices and debt. They combine aggregate and micro data to estimate the disposition of free cash generated by home equity extraction for, among other things, aggregate personal consumption expenditures, and investment.

This paper adds to the existing literature in a number of dimensions. First, it exploits a unique, survey-based micro data set on Canadian households from 1999 to 2007. The data set provides detailed information on the many sources and uses of debt. Respondents to the survey are able to list multiple outstanding balances on leases, loans, lines of credit, mortgages and credit/charge cards. The data set also reports the primary purposes of each debt component, such as financing of consumption, home improvement, acquisition of financial investment, or paying off debts. This aspect of the data enables us to not only explore the relationship between house prices and debt,

\footnotetext{
${ }^{4}$ Home renovations can be thought of as an investment, while at the same time contributing to a stream of housing services. Therefore, in effect, home-equity debt associated with home improvements/renovations would lead to changes in housing services consumption as well.

${ }^{5}$ Unfortunately, our data does not allow us to distinguish between new or existing homeowners who take on home purchase debt, and thus the main focus of the paper is on home-secured debt of non-movers - which includes mortgage refinancing, but not home purchase mortgages - and on other non-home-secured debt.
} 
but also, by extension, the relationship between house prices and consumption directly through the use of debt, which is new to the literature. ${ }^{6}$

Next we apply the quantile regression approach to the data to explore the relationship between regional house prices and total household debt. We find that house prices are positively associated with household debt all along the conditional debt distribution. The association is largest at the upper end of the conditional debt distribution, which is not surprising, given that higher house prices generally mean larger mortgages for first-time and repeat homebuyers, who make up the upper end of the household debt distribution. More interesting is the finding of the positive relationship between house prices and the lower end of the conditional debt distribution, which suggests that the association goes beyond the purchase of real estate.

This result motivates the study of the relationship between house prices and non-mortgage debt, which is also new to the literature. House price inflation may imply different borrowing behaviour depending on household type. While an increase in house prices is generally associated with a wealth effect for homeowners, its size (and even direction) depends on the household's current tenure status, future housing needs and intentions regarding bequeathal. Higher house prices may also relax credit constraints for some households, enabling them to take on additional debt for consumption. Consequently, the question of the relationship between house prices and household borrowing is necessarily an empirical one. To this end, we regress non-mortgage debt on regional house prices - controlling for a number of macroeconomic factors and household characteristics. Given that we are looking only at households with positive non-mortgage debt, we control for selection bias using the Heckman sample selection correction model. In our regression analysis, we find a positive and statistically significant relationship for homeowners. More specifically, a one percent increase in house prices is associated with a 0.36 percent increase in outstanding homeowner non-mortgage debt. Furthermore, we find that this relationship is preserved for homeowners of all ages.

Finally, we combine the results from the non-mortgage debt regressions with the reported uses of this debt, with a particular focus on non-housing consumption. On average, homeowners used about 40 percent of their non-mortgage debt (across all instruments) for non-housing consumption.

\footnotetext{
${ }^{6}$ Mian and Sufi (2009) lack direct information on the uses of debt and can therefore only make indirect inferences, by exclusion, on the relationship between house prices and consumption through the use of debt.
} 
Together with an increase in national house prices of 52 percent over the sample period, we come to the conclusion that roughly 25 percent of net non-mortgage debt flows were associated with house price increases, and used for non-housing consumption. In a sense, this can be thought of as a conservative lower bound for the relationship between house prices and aggregate consumption (as defined in the Canadian System of National Accounts). In this analysis, we focus on nonhousing consumption, but housing consumption is included in measures of aggregate consumption. Moreover, our definition of non-mortgage debt is not meant to include mortgage refinancing (in

all its forms), which can be connected to consumption spending. Given this, it is likely that the relationship between house prices, debt and consumption is larger in the aggregate.

The paper proceeds as follows. Section 2 provides a discussion on the complex relationship between house prices, debt and consumption. Section 3 details the household-level and macroeconomic data used in the empirical analysis, and presents some summary statistics and preliminary analysis. Section 4 outlines the two empirical models used to study the relationship between house prices and household debt (both total and non-mortgage), and presents the estimation results. Section 5 examines how debt is used (i.e. for consumption and portfolio re-balancing), and then links house price increases, through non-mortgage debt, to consumption expenditures. Finally, Section 6 presents conclusions from this work.

\section{Overview of House Price Effects}

House price increases can be linked to household borrowing through several channels. First, there are renters buying into the hot housing market, and the current level of house prices (relative to income) affects the size of mortgages taken out to finance home purchases and overall household debt. Second, there are existing homeowners who change homes and adjust their housing consumption in an environment of rising house prices. They experience the effects of house price increases both when they sell their existing home and buy a new one, adjusting their debt position accordingly in the process (mortgage debt and other home equity debt). Third, there are existing homeowners who do not adjust their housing consumption with increases in their home equity, but can borrow against this equity using different debt instruments. These include the refinancing of already outstanding mortgage balances at higher amounts and using other forms of home equity debt, such as HELOCs and HELs. Finally, the ability to borrow of renters who do not make a transition into 
homeownership may also be affected, indirectly, by increasing house prices.

Households take into account many factors when deciding to transition from renting into homeownership, to remain a homeowner, and to adjust their housing consumption by moving homes. Due to data limitations, however, we are not be able to separately identify recent homebuyers from those that have owned their homes for a while. We therefore group these two types together and focus on the comovement of their debt with house prices. These households may adjust their debt position (in particular, relative to income) for portfolio rebalancing and consumption purposes. The former includes changing the mix of assets in the household portfolio-for example, changing the mix of housing and financial assets, or changing the quality of assets ${ }^{7}$ —and re-optimizing the structure of debt to reduce the costs associated with its servicing-for example, substituting more expensive unsecured debt for home equity based debt. The existing literature has used information on changes in household situation and other household characteristics (constrained versus unconstrained) to try to figure out how different types of households use their debt (constrained households are assumed to use it for consumption, while unconstrained households are assumed to focus on portfolio rebalancing).

Existing homeowners who have a long expected housing tenure and are not credit-constrained when choosing their consumption path, as shown in Sinai and Souleles (2005) and Campbell and Cocco (2007), are perfectly hedged against house price fluctuations. As a result, movements in house prices have no effect on their real wealth and so the propensity to borrow for consumption out of housing gains is zero. However, these unconstrained households may still incur housing debt to rebalance their portfolio (to reduce exposure to risky housing assets and invest in safer and more liquid assets, for example). Alternatively, unconstrained homeowners who do not value housing bequests and wish to consume part of their housing capital, may choose to borrow against unexpected increases in home equity, and this desire to borrow may increase as the homeowner ages (this is because their life-horizon, and therefore their expected housing tenure, becomes shorter). This latter scenario involves borrowing for consumption.

On the other hand, it is possible that existing homeowners are credit constrained and would like to borrow today to smooth consumption, but are unable to do so. There are several reasons why this

\footnotetext{
${ }^{7}$ This includes using home equity for improvement/renovation of the same home, which results in the increase in the value of the home.
} 
may be the case. They may have equity in their homes, but it may not be sufficient to avoid paying additional borrowing costs, which may exceed the benefits of borrowing, keeping homeowners' equity trapped in the house. For example, in the time period we study, this could have been the case of mortgage refinancing with a LTV ratio above conventional levels, requiring the purchase of mortgage insurance and payment of the premium as a percentage of the balance. An increase in house prices would then reduce LTV ratios and give otherwise liquidity constrained homeowners access to home equity - in particular, through cheaper financing options such as conventional (low LTV) mortgage refinancing and HELOCs and HELs - or reduce the costs of high-LTV refinancing. ${ }^{8}$ Alternatively, if recent homebuyers are not yet at the point of being able to refinance their mortgage, they nevertheless experience an increase in housing wealth and may find it beneficial to turn to unsecured borrowing to finance consumption (this debt can be consolidated in the future against further house price increases). ${ }^{9}$ More generally, these households may also be very sensitive to changes in the relative costs of different forms of debt, and borrow against increases in housing equity to change the structure of their debt and reduce debt servicing costs, with savings on interest used for consumption. Alternatively, they may borrow and invest in improving the quality of their housing assets by doing renovations in their house, which could not have been financed without house price increases.

Home equity extraction in both the cases of constrained and unconstrained households would result in increases in household home-secured and total outstanding debt (in particular, relative to income), but its effect on housing LTV ratios and the household balance sheet, more generally, would be ambiguous. If households extract equity from their homes at a faster rate than the rate of house price appreciation, the housing LTV ratio would deteriorate, but the overall condition of their balance sheet would deteriorate only if they also consume these resources. If households

\footnotetext{
${ }^{8}$ During our sample period, to qualify for a HELOC in Canada, homeowners must have at least twenty percent equity in their home, and can borrow against any equity exceeding the twenty percent. HELs are also known as second mortgages. Starting in 2008, a number of measures have been adopted to tighten mortgage regulations.

${ }^{9} \mathrm{In}$ each of the examples in this paragraph, it is assumed that the homeowners intend to stay in their current dwellings for the foreseeable future. For a homeowner that is looking to move in the near future - whether to a more or less expensive home - an increase in the value of their current home is offset by any increases in the price of their next house. If, in the process of moving homes, homeowners aim to maintain their equity holdings (i.e. they are not looking to extract equity in the process of switching homes), an increase in the value of their current home should not induce them to borrow for consumption. If, on the other hand, the homeowner intends to withdraw equity in the transaction, it is possible that the homeowner will borrow off of the increased value in the current home. To the extent that this non-mortgage debt is used for consumption, there exists a positive relationship between house prices and consumption for this type of household.
} 
take on home equity debt and use the resources for investment in other assets, their overall wealth position may not change. Borrowing to optimize the structure of household debt may also lead to improvement in the household balance sheet, as savings from reduced interest costs can be applied to asset accumulation. Because understanding the interplay between house prices, debt and the uses of debt is our ultimate goal, in our regression analysis we use debt alone as the dependent variable and not other normalized measures (such as debt-to-income or debt-to-asset ratios). As mentioned above, unless household incomes grow at the same rate as debt (which has not been the case recently), the average debt-to-income ratio (as well as the whole distribution) will increase following an increase in debt. Normalizing debt by income or assets would only convolute the analysis and reduce our ability to link house prices to consumption.

To complete the picture, for those that rent their homes, the connection between house prices, non-home based debt (they do not have home-secured debt) and consumption is less clear. If rents move in tandem with house prices, then any increase in house prices may lead to a reduction in consumption as renters devote more resources to paying rent. ${ }^{10}$ However, there exists a different channel through which house prices may affect renters' (as well as a homeowner's) ability to borrow to finance, among other things, consumption. This is a supply channel. If homeowners are borrowing against the increased equity in their homes associated with rising house prices, banks may wish to rebalance their portfolio of secured and unsecured debt by loosening the conditions for unsecured borrowing, which would benefit renters (as well as homeowners who are unable to borrow against equity in their home due to collateral constraints). ${ }^{11}$ While little empirical or even anecdotal evidence exists in support of this lending channel, it remains a possibility and could connect house prices with the debt and consumption of renters. Given these competing factors, the overall effect of house prices on those that rent their homes is ambiguous.

\footnotetext{
${ }^{10}$ For renters looking to purchase a home in the near future, an increase in house prices may also lead to a reduction in consumption as these renters increase their savings. However, as Engelhardt (1994) points out, increases in house prices may discourage renters from saving for a down payment on a house.

${ }^{11}$ The securitization of mortgage debt may be another way that banks rebalance their portfolio of secured and unsecured debt, and this may offset the proposed mechanism.
} 


\section{$3 \quad$ Data and Summary Statistics}

In the analysis in the next section, we make use of both household-level data and macro data, including regional house prices. In this section, we detail the data sources and provide summary statistics, along with some preliminary analysis.

\subsection{Household-Level Data: CFM Overview}

We use household-level data from the Canadian Financial Monitor (CFM) survey conducted by the marketing research firm Ipsos Reid. The data set contains demographic characteristics of households, as well as detailed information on household liabilities and some assets. The survey had originally been launched with the purpose of distributing information on a representative sample of households to banking and financial institutions in Canada for marketing purposes-however, it has begun to be used by researchers for the analysis of financial stability (see Dey, Djoudad and Terajima, 2008, Faruqui, 2008 and 2010, Allen, Damar and Martinez-Miera, 2012).

The sampling frame for the CFM is built from names that are purchased from targeted mailing lists. As respondents to these mailing lists confirm their participation, they are added to the database from which the CFM sample is drawn. The CFM employs a quota sample with targeted sample sizes - that is, sampling is done until a specific sample size has been achieved. ${ }^{12}$ The survey provides household weights that are calibrated to fit seven dimensions: geographical region, home ownership status, employment status of the household head, household size, city size, the age of the household head, and household income. These weights can be used to aggregate sample quantities to their population counterparts, and in what follows, all reported statistics will be population values unless otherwise stated.

We make use of CFM data from 1999 to 2007. The survey is conducted at a monthly frequency, with about 1000 households interviewed each month that are chosen to be representative of the Canadian population, providing a total sample of around 12,000 households per year. In order to reduce non-response, households are asked to report most monetary values within ranges, rather than supplying exact values. For our analysis, we replace the reported ranges with their mid-points and use these as our observations for households. While the ranges for reported values of debt

\footnotetext{
${ }^{12}$ For comparison, the Canadian Survey of Financial Security and the U.S. Survey of Consumer Finances are two-stage probability samples.
} 
are relatively narrow, they become wider at higher values and are top-coded at $\$ 500,000 .{ }^{13}$ That is, the highest level of debt that may be reported for a single instrument is " $\$ 500,000$ or more", which we set to $\$ 500,000$. This can be an issue for getting an accurate measure of outstanding mortgage balances, since many mortgages may exceed $\$ 500,000$ (this is not the case for most other debt categories). This likely truncates the upper end of the total debt distribution and therefore affects measured moments in the data-particularly averages. However, our regression results are not affected by this issue for reasons addressed below.

Faruqui and Lai (2011) compare the CFM to the Survey of Financial Security (SFS), a periodic survey of household finances conducted by Statistics Canada in 1999 and 2005 (the two years that overlap our study). In order to compare the CFM to the SFS, they use the mid-points of the ranges as the observations for households (most SFS respondents provide exact responses for different debt categories). They find that despite the differences in reporting between the two surveys - mid-ranges versus exact point estimates - the CFM debt distribution is very similar to that in the SFS, and therefore they conclude that CFM can be used for the analysis of household debt.

The survey asks households to report outstanding balances on a number of debt instruments, including mortgages, personal loans (including home equity loans), credit/charge cards, lines of credit (including home equity lines of credit), and leases. For each of these categories, respondents are able to list multiple sources of outstanding debt to give a clear picture of household liabilities. ${ }^{14}$ For all components of debt we use the mid-points of the reported ranges and create real values by deflating by the quarterly consumer price index to measure the real burden of currently outstanding debt. Outstanding non-mortgage debt for each household is then calculated as the sum of real balances on personal loans, lines of credit and leases. Total household debt is defined as nonmortgage debt plus mortgage debt and any outstanding credit card debt. ${ }^{15}$

The CFM also contains information on household income and other demographic variables. Like

\footnotetext{
${ }^{13}$ In fact, the top debt category changes over time. We set the top value at $\$ 500,000$ so that our debt totals are consistent across time.

${ }^{14}$ Respondents can report the balances on up to eleven credit/charge cards, nine loans, eight mortgages, five lines of credit and four leases.

${ }^{15}$ Of note, equity extraction from mortgage refinancing cannot be separated from overall mortgage debt from 1999 to 2006. As shown in Bailliu, Kartashova and Meh (2012), mortgage refinancing played an important role in the overall increase in Canadian debt from 1999 to 2009. So although the data capture the effect of mortgage refinancing on overall debt, refinancing cannot be analyzed on its own in our framework. Credit card debt is the outstanding balance on a credit card after the last payment, and therefore does not include balances that are paid off each month.
} 
debt, income is reported within ranges. However, unlike debt, we do not attempt to construct a continuous income variable, and instead use the reported income values to create income dummies to be used as control variables. ${ }^{16}$ The CFM also reports the age and level of education of the household head, as well as the number of adults and children in the household. From this last piece of information, we construct a measure of adult equivalents by adding up all individuals in the household, while assigning a weight of 1.0 to each adult and and a weight of 0.5 to each child (below the age of 14). Respondents also report if they own a personal business. Finally, in order to match the household data with aggregate quarterly data, we combine households in each quarter by stacking monthly observations.

\subsection{Household-Level Data: CFM Data Analysis}

In this subsection, we provide a summary analysis of the CFM. Table 1 presents some relevant statistics built from the household data, including the homeownership rate, total household debt, non-mortgage debt, and debt participation rates (which are defined as the fraction of all households with non-zero total and non-mortgage debt). The reported average debt holdings include households that do not have debt. While the CFM homeownership rate in 2001 (65.7 percent) is almost identical

Table 1: Household Summary Statistics

\begin{tabular}{|c|c|c|c|c|c|c|c|}
\hline \multirow[b]{2}{*}{ Year } & \multirow{2}{*}{$\begin{array}{c}\text { Homeowner- } \\
\text { ship Rate (\%) }\end{array}$} & \multicolumn{3}{|c|}{ Total Debt } & \multicolumn{3}{|c|}{ Non-Mortgage Debt } \\
\hline & & Partic. (\%) & Mean & Stdev. & Partic. (\%) & Mean & Stdev. \\
\hline 1999 & 64.4 & 71.8 & 43,393 & $(65,333)$ & 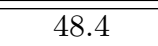 & 9,097 & $(20,987)$ \\
\hline 2000 & 64.2 & 73.4 & 43,310 & $(64,294)$ & 52.1 & 10,087 & $(26,002)$ \\
\hline 2001 & 65.7 & 72.0 & 44,648 & $(64,102)$ & 50.6 & 9,982 & $(21,247)$ \\
\hline 2002 & 65.8 & 70.8 & 46,422 & $(67,849)$ & 50.0 & 10,556 & $(24,402)$ \\
\hline 2003 & 71.9 & 69.2 & 45,954 & $(67,068)$ & 49.1 & 10,129 & $(20,404)$ \\
\hline 2004 & 69.0 & 69.1 & 45,520 & $(69,717)$ & 48.5 & 10,956 & $(26,317)$ \\
\hline 2005 & 67.2 & 69.2 & 48,189 & $(75,316)$ & 48.3 & 11,747 & $(29,467)$ \\
\hline 2006 & 66.1 & 69.5 & 46,412 & $(75,330)$ & 47.8 & 11,711 & $(27,835)$ \\
\hline 2007 & 66.2 & 69.5 & 47,774 & $(79,625)$ & 48.3 & 11,408 & $(26,366)$ \\
\hline
\end{tabular}

Note: All dollar values are in 2002 quarter 1 dollars. Population weights are used to calculate population values for each variable. The figures for total and non-mortgage debt are for all households, including those with zero debt. The participation rates (Partic.(\%)) are defined as the fraction of all households with non-zero total and non-mortgage debt. Due to top coding (we set the highest debt level a household can report for a single debt instrument is $\$ 500,000$ ), our estimates for total debt likely underestimate the true values.

to that reported in the census (65.8), the CFM appears to understate the growth in homeownership

\footnotetext{
${ }^{16}$ The income ranges are broader than the debt categories and are top coded at $\$ 150,000$.
} 
Table 2: Household Characteristics by Quartile of the Total Debt Distribution

\begin{tabular}{l|cccc} 
& \multicolumn{5}{|c}{ Quartile of the Debt Distribution } \\
1999 & 1 & 2 & 3 & 4 \\
\hline Age of Household Head & 47 & 44 & 42 & 39 \\
University Degree (\%) & 21 & 27 & 32 & 42 \\
Home Ownership Rate (\%) & 38 & 57 & 96 & 99 \\
Non-Mortgage debt & 1,360 & 12,227 & 13,296 & 23,757 \\
Mortgage Debt & 79 & 4,373 & 49,872 & 126,374 \\
Total Debt & 2,838 & 19,289 & 65,481 & 154,127 \\
\hline \hline 2007 & \multicolumn{5}{|c}{} \\
\hline Age of Household Head & 50 & 49 & 46 & 41 \\
University Degree (\%) & 25 & 32 & 34 & 43 \\
Home Ownership Rate $(\%)$ & 43 & 58 & 93 & 99 \\
Non-Mortgage debt & 1,647 & 13,051 & 19,350 & 31,510 \\
Mortgage Debt & 97 & 3,249 & 44,001 & 149,789 \\
Total Debt & 2,926 & 19,009 & 67,049 & 186,424 \\
\hline
\end{tabular}

Note: All dollar values are in 2002 quarter 1 dollars. Due to top coding (we wet the highest debt level a household can report for a single debt instrument is $\$ 500,000$ ), our estimates of total debt and mortgage debt at the top end of the debt distribution likely underestimate the true values.

reported in the census over the sample period - the CFM homeownership rate in 2006 is 66.1 percent versus 68.4 in the census. ${ }^{17}$ Over the entire sample period, mean total debt grew by ten percent, while non-mortgage debt grew by 25 percent.

In Table 2 we present some household characteristics based on quartiles of the total debt distribution for 1999 and 2007. We see that those at the top end of the debt distribution tend to be younger and more educated.

They are also much more likely to be homeowners and have significantly more mortgage debt, which is likely a reflection of the fact that they are recent, first-time home buyers and have only just started paying off their mortgages. Finally, those at the top end of the debt distribution also have higher non-mortgage and outstanding credit/charge card debt.

Debt holdings are also expected to exhibit some life cycle effects. In order to explore this further, we regress total household debt and non-mortgage debt on 63 year-cohort dummies, which correspond to seven age cohorts and nine years of data. Each of the estimated coefficients on the year-cohort dummies captures mean cohort-year total and non-mortgage debt. Figure 1 plots the evolution of total and non-mortgage debt over the life cycle, where each line corresponds to a

\footnotetext{
${ }^{17}$ The Canadian Census is conducted every five years, the most recent (that fall into our period of study) being in 2001 and 2006.
} 
Figure 1: Life-Cycle Patterns in Household Debt

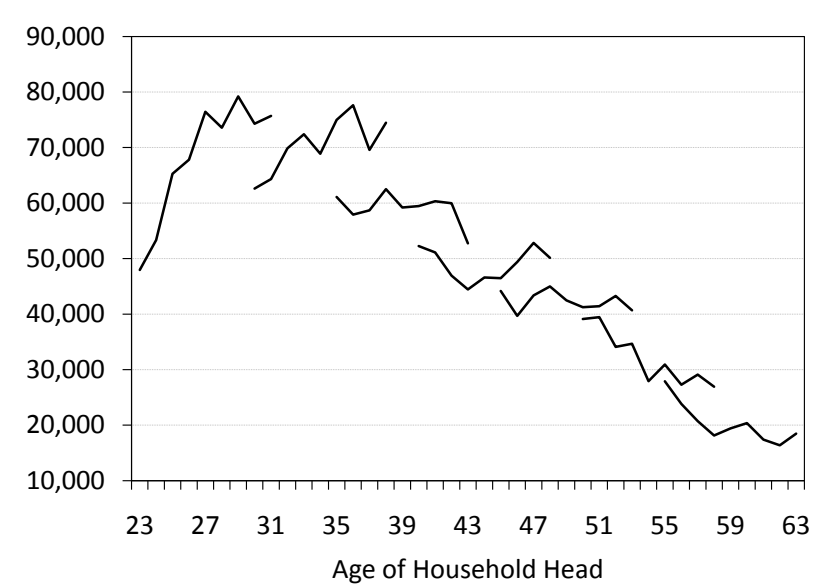

(a) Total Debt

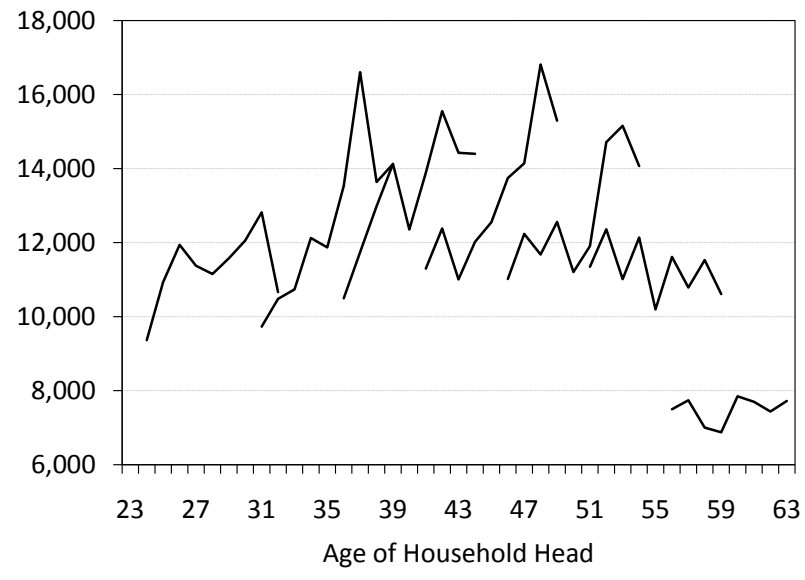

(b) Non-Mortgage Debt

Note: The figures plot the mean cohort-year values of total household debt and non-mortgage debt, which are the coefficient estimates (plus the constant) on year-cohort dummies in a regression of debt on 63 year-cohort dummy variables. Due to top coding (the highest debt level a household can report for a single debt instrument is $\$ 500,000$ ), our estimates for total debt likely underestimate the true values.

different cohort. Our seven age cohorts are defined by the age of the head of the household in 1999 and the age groups are: 23-29, 30-34, 35-39, 40-44, 45-49, 50-54 and 55-59. ${ }^{18}$

While total debt exhibits a clear life-cycle pattern, this is not the case for non-mortgage debt. For total debt, the age profile is hump shaped over the life cycle - it increases early on in life, but then declines over time. Since mortgage debt makes up the majority of total household debt, the results from the total debt regressions are in line with the story of young households buying homes and paying off their mortgage as they age. A similar profile for debt over the life cycle is predicted in Iacoviello and Pavan (2009). For non-mortgage debt, there is no clear life-cycle pattern, other than debt being lower in each year for the oldest cohort. Other than that, the age profile is relatively flat along the life cycle, with significant growth in non-mortgage debt within the cohorts throughout the sample period.

\subsection{House Price Data}

While the CFM does ask respondents to report the values of their real estate properties, there are a significant number of homeowners that do not report the value of their home. For those

\footnotetext{
${ }^{18}$ The first cohort (23-29) is larger than the others in order to increase the number of observations in the group.
} 
that do report the value of their real estate properties, they are asked to do so within the same ranges as the other monetary fields. In the case of real estate, top coding becomes an important issue since many people have homes with values in excess of $\$ 500,000$, the highest value that they can report. Moreover, in the final years in our sample period, respondents are only asked to report the total market value of their real estate properties (primary residence plus any vacation and investment properties), which exacerbates the top coding issue. Given the problems with the reported household-specific measures of housing wealth, we use regional house prices instead. ${ }^{19}$ We match households with regional house prices acquired from the Canadian Real Estate Association's Multiple Listing Service (MLS). Using data on respondent postal codes allows us to match households to house prices in sixteen distinct regions. The regions are based on the first letter of the respondent's postal code and are: Newfoundland and Labrador, Nova Scotia, Prince Edward Island, New Brunswick, Eastern Quebec, Metropolitan Montreal, Western Quebec, Eastern Ontario, Central Ontario, Metropolitan Toronto, Southwestern Ontario, Northern Ontario, Manitoba, Saskatchewan, Alberta, and British Columbia. ${ }^{20}$

House prices are deflated using the consumer price index (CPI). Real house prices rose steadily in every region throughout the sample period, with Alberta experiencing the largest cumulative growth (110 percent) and Southwestern Ontario experiencing the least cumulative growth (24 percent). Using regional house prices is important because it introduces not only time variation, but crosssectional variation as well, which is important for identifying the relationship between house prices and debt, and by extension, consumption. ${ }^{21}$

\section{House Prices and Household Debt}

In this section, we examine the relationship between house prices and household debt. We begin by looking at the relationship between house prices and total household debt, and then focus on the association between house prices and non-mortgage debt. As summarized above, a number

\footnotetext{
${ }^{19}$ Individual market prices are only available for home purchase-sale transactions, and get reflected in the mortgage contracts. In the case of mortgage refinancing and home equity borrowing, house values are determined through assessment (if at all) and do not represent realized market prices.

${ }^{20}$ Note that eight of these regions are entire provinces, but that Ontario and Quebec - Canada's two largest provinces both in terms of population and land mass - are divided into five and three regions, respectively.

${ }^{21}$ Moreover, as pointed out in Attanasio et al. (2009), regional house prices are likely related to permanent income, since they might be influenced by the level of productivity and economic activity in different regions. They use this to assess whether movements in consumption and house prices are driven by some common factor.
} 
of studies have attempted to establish a connection between housing wealth and consumption by either regressing consumption directly on house prices, or by first looking at the relationship between household debt and house prices, and then making inferences about consumption. Regardless of the approach, these studies do not claim to identify a causal relationship between housing wealth and consumption (or even debt). The difficulty in finding instruments that are predictive of house prices, but unrelated to unobserved factors that affect consumption and debt, has limited assertions of causality. ${ }^{22}$ In line with this literature, we do not claim to identify a causal relationship, but provide further refined estimates of housing wealth effects using unique, detailed household-level data.

\subsection{Total Household Debt}

We begin this subsection by examining the unconditional total debt distribution, and then use quantile regression to plot the total debt distribution, conditional on house prices. As noted earlier, we do not normalize the debt distribution by income (as in Dynan and Kohn, 2007), since our ultimate goal is to focus on the extent to which debt is used for consumption. Normalizing debt by income would only confound this analysis. Figure 2 presents the evolution of the $10^{\text {th }}$, $50^{\text {th }}$ and $90^{\text {th }}$ percentiles of the total debt distribution (conditional on having positive debt), as well as the mean. While all three percentiles along the debt distribution and the mean increase together from 1999 to 2003 , the lines begin to diverge thereafter. The $10^{\text {th }}$ and $50^{\text {th }}$ percentiles decrease and by 2007 are fifteen and eight percent below their 1999 values, respectively. The $90^{\text {th }}$ percentile, on the other hand, continues to increase throughout the sample period and by 2007 is 21 percent higher than the 1999 value. It is clear from this that much of the increase in mean debt (fourteen percent over the sample period) was driven by increases in the upper end of the debt distribution. ${ }^{23}$ What is not clear in Figure 2 is the extent to which the dispersion of total debt increased: from 1999 to 2007, the standard deviation of the total debt distribution increased by 25 percent. In general, the evolution of the total household debt distribution is consistent with the expected consequences of increasing house prices on mortgage debt, given that the top end of

\footnotetext{
${ }^{22}$ The one exception in this literature is Mian and Sufi (2009), who use land topology-based housing supply elasticity as an instrument for house prices. Even with this instrument, they make no claims of causality. We do not have the data necessary to create a similar instrument for Canada.

${ }^{23}$ We also know from Table 1 that the total debt participation rate changed very little over time and therefore does not explain the observed patterns.
} 
the debt distribution is populated primarily by young homeowners with high debt levels associated with the recent purchase of a home (we know this from Table 8) or through mortgage refinancing. ${ }^{24}$

Figure 2: Distribution of Total Household Debt

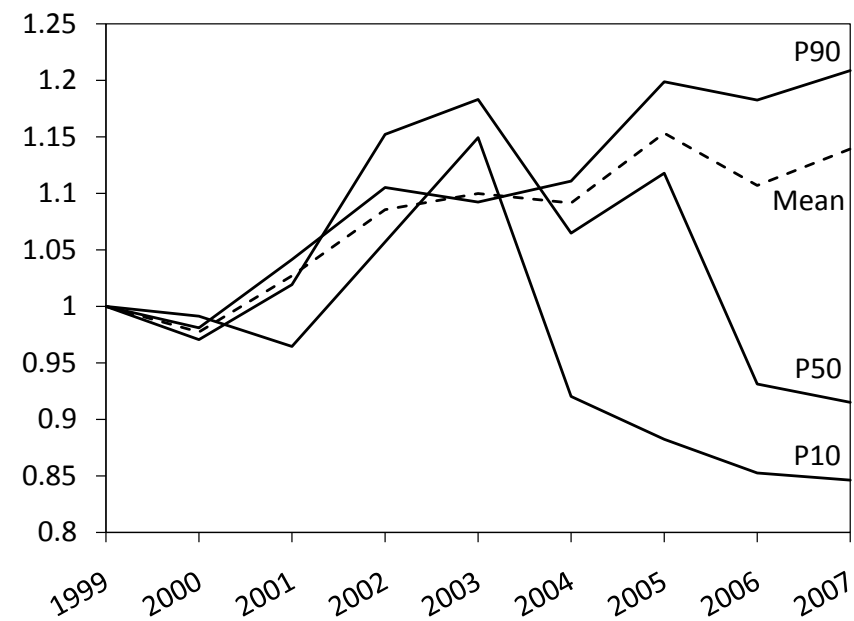

Note: P10, P50 and P90 refer to the $10^{t h}, 50^{t h}$ and $90^{t h}$ percentiles, respectively. This distribution is conditional on households having positive debt.

In order to examine the relationship between house prices and the distribution of total household debt more formally, we use quantile regression (for a formal definition of quantile regression, see Appendix A). Our baseline regression model is:

$$
\operatorname{debt}_{i k t}=\beta_{0}+\beta_{r} r_{t}+\beta_{p} p_{k t}+\beta_{y} y_{i t}+\beta_{x} X_{i t}+\beta_{z} Z_{k t}+\sum_{t=2}^{T} \beta_{t} d_{t}+\epsilon_{i k t}
$$

where $d e b t_{i k t}$ is the logarithm of total debt for household $i$ in region $k$ at time $t, r_{t}$ is the real interest rate (we use the Bank of Canada overnight rate minus CPI inflation), $p_{k t}$ is the logarithm of regional house prices, and $y_{i t}$ is a dummy for income group. We use three income groups: one for those households whose reported income the previous year was between $\$ 35,000$ and $\$ 49,999$, one for those with incomes between $\$ 50,000$ and $\$ 99,999$, and one for those with incomes exceeding $\$ 100,000$. The reference group for income are those households who earned less than $\$ 35,000$ in

\footnotetext{
${ }^{24}$ Note that as households who were at the low end of debt distribution-but can afford to buy a home - move to the upper end of the debt distribution through the purchase of a home, the remaining renters may be those who have even less debt. This change in the composition may explain the decline in the level of debt in the 10th percentile.
} 
the previous year. ${ }^{25} X_{i t}$ is a vector of household characteristics including the age of the household head, as well as its squared and cubed terms, dummies for whether the head of the household has a high school diploma or a university degree (the reference group here being those that do not have a high school diploma), whether anyone in the household owns a business, the equivalent number of adults in the household, and a dummy for whether the household owns their home. ${ }^{26} Z_{k t}$ is a vector of region-specific control variables, which includes labour productivity and the unemployment rate (proxies for income differences). ${ }^{27}$ We also include a set of quarterly time dummies, $d_{t}$, to pick up any common macroeconomic factors, including regulatory changes in the mortgage market. ${ }^{28}$ Finally, $\epsilon_{i k t}$ is an error term with mean zero.

The regression framework is similar to the regressions run in Dynan and Kohn (2007), except that their dependent variable is total household debt over income. Because their debt-to-income variable has large outliers they use median regression to down-weight the outliers. Our debt data does not have the same extreme outliers. This is, in part, due to the fact that debt categories are top coded at $\$ 500,000$, which limits the amount of debt any household can have in our data. However, this could create a new problem when examining the conditional distribution of debt. Namely, if the area around the quantile we are examining includes individuals with reported debt categories at $\$ 500,000$, you will not be observing the true quantile. In our analysis, the top quantile we look at is the $90^{t h}$ percentile, and at no point in time does the $90^{\text {th }}$ percentile of total debt exceed $\$ 500,000$, meaning that no individual around this point reports a single debt category at $\$ 500,000$. And since quantile regression estimates are not affected by the distribution of the dependent variable around that point, our results are robust to top coding issues.

We run the regressions at the $10^{t h}, 25^{t h}, 50^{t h}, 75^{t h}$ and $90^{t h}$ percentiles, and present the results in Table 3. To control for selection (about thirty percent of households have no debt) we use a methodology similar the one outlined in Buchinsky and Hahn (1998). More specifically, we first

\footnotetext{
${ }^{25}$ These numbers for income are all in nominal terms and are before taxes.

${ }^{26} \mathrm{~A}$ homeowner here is defined as anyone who owns real estate.

${ }^{27}$ Of note, labour productivity and unemployment rates are reported at the provincial level, and therefore there is no variation in these variables across the different regions in Quebec and Ontario. Moreover, labour productivity is reported on an annual frequency. Labour productivity is defined as total output (deflated by CPI) per hour worked in the business sector. Unemployment rates are used on a quarterly frequency.

${ }^{28}$ From 1999 to 2007, there were a number of regulatory changes and product innovations in the mortgage market affecting the ability of households to take on mortgage debt. A time line for these changes is provided in Appendix B. We have run our regressions for total and non-mortgage debt with dummies for the regulatory changes and product innovations in place of time dummies and found that this has little effect on the coefficients of interest.
} 
estimate a selection equation where the dependent variable is a positive debt indicator and the explanatory variables are the same as in (1). We then calculate in inverse Mill's ratio, and include this, along with its squared value, as explanatory variables in the quantile regressions. ${ }^{29}$ We also estimate a mean regression model using the standard Heckman (1979) sample selection correction and report the unadjusted point estimates - that is, the estimates for the mean regression model apply only to those with positive debt. For both the quantile and mean regressions, the results are very similar if we do not control for selection.

The mean regression point estimate on house prices is significant at the $1 \%$ level and indicates that a one percent increase in house prices is associated with a 0.322 percent increase in total debt. A look at the quantile regression estimates shows that the coefficient on the house price variable is generally larger one moves up the conditional total debt distribution. More specifically, a one percent increase in house prices is associated with a 0.125 percent increase in the $10^{t h}$ percentile of the debt distribution, and a 0.461 percent increase at the $90^{\text {th }}$ percentile. This implies that house price increases are not only associated with increases in debt along all the debt distribution, but also with increases in the dispersion of household debt. The fact that house price increases have a larger effect on the top end of the debt distribution is likely a reflection of households borrowing more to purchase a residence, since homeowners make up the top end of the debt distribution. What is interesting in these results is that house prices are positively associated with the lower end of the total debt distribution. This suggests that the relationship between house prices and debt goes beyond the act of purchasing a home and motivates our study of the relationship between house prices and non-home purchase debt, which we undertake in the following subsection.

First, however, in line with the related literature, Table D1 (Appendix D) presents the results of our regression analysis using house price growth (the quarter-over-quarter annual growth rate of regional house prices), instead of the level of house prices. ${ }^{30}$ We find that house price growth is negatively associated with total debt at all points along the conditional debt distribution, and the

\footnotetext{
${ }^{29}$ We estimate the selection model using the semiparametric maximum likelihood estimator developed in Klein and Spady (1993). We make no adjustment to the standards errors in the quantile regressions.

${ }^{30} \mathrm{~A}$ number of related studies examine the relationship between the growth rate of house prices and either consumption, consumption growth or the change in debt. Cocco and Campbell (2007) focus on the relationship between house price growth and consumption growth, and Mian and Sufi (2009) look at the association between house price growth and debt growth. Attanasio et al. (2009) present the results from regressing the level of consumption on house price growth, but the main results of their paper are the level-on-level (in logs) results. Attanasio et al. point out that the use of the level of house prices might be expected to better capture any pure wealth effects, since under the permanent income hypothesis theory, it should be the level of resources that affect the level of consumption.
} 
Table 3: Total Debt Quantile Regression Results (with House Price Level)

\begin{tabular}{|c|c|c|c|c|c|c|}
\hline & 0.1 & 0.25 & $\begin{array}{c}\text { Quantile } \\
0.5 \\
\end{array}$ & 0.75 & 0.9 & Mean \\
\hline House Price & $\begin{array}{c}0.125^{*} \\
(0.06)\end{array}$ & $\begin{array}{c}0.384^{* * *} \\
(0.03)\end{array}$ & $\begin{array}{c}0.487^{* * *} \\
(0.02)\end{array}$ & $\begin{array}{c}0.498^{* * *} \\
(0.01)\end{array}$ & $\begin{array}{c}0.461^{* * *} \\
(0.01)\end{array}$ & $\begin{array}{c}0.322^{* * *} \\
(0.02)\end{array}$ \\
\hline Homeowner & $\begin{array}{c}3.558^{* * *} \\
(0.22)\end{array}$ & $\begin{array}{c}2.390^{* * *} \\
(0.10)\end{array}$ & $\begin{array}{c}1.749 * * * \\
(0.06)\end{array}$ & $\begin{array}{c}1.445^{* * *} \\
(0.05)\end{array}$ & $\begin{array}{c}1.369^{* * *} \\
(0.05)\end{array}$ & $\begin{array}{c}1.838^{* * *} \\
(0.01)\end{array}$ \\
\hline Interest Rate & $\begin{array}{l}0.036 \\
(0.04)\end{array}$ & $\begin{array}{l}0.031 \\
(0.02)\end{array}$ & $\begin{array}{l}0.002 \\
(0.01)\end{array}$ & $\begin{array}{l}-0.002 \\
(0.01)\end{array}$ & $\begin{array}{l}-0.015 \\
(0.01)\end{array}$ & $\begin{array}{c}-0.027^{*} \\
(0.01)\end{array}$ \\
\hline Income 1 & $\begin{array}{c}2.156^{* * *} \\
(0.16)\end{array}$ & $\begin{array}{c}0.944^{* * *} \\
(0.08)\end{array}$ & $\begin{array}{c}0.368^{* * *} \\
(0.05)\end{array}$ & $\begin{array}{c}0.236^{* * *} \\
(0.04)\end{array}$ & $\begin{array}{c}0.239^{* * *} \\
(0.04)\end{array}$ & $\begin{array}{c}0.666^{* * *} \\
(0.01)\end{array}$ \\
\hline Income 2 & $\begin{array}{c}2.469^{* * *} \\
(0.16)\end{array}$ & $\begin{array}{c}1.234^{* * *} \\
(0.08)\end{array}$ & $\begin{array}{c}0.625^{* * *} \\
(0.05)\end{array}$ & $\begin{array}{c}0.491^{* * *} \\
(0.04)\end{array}$ & $\begin{array}{c}0.504^{* * *} \\
(0.04)\end{array}$ & $\begin{array}{c}0.965^{* * *} \\
(0.02)\end{array}$ \\
\hline Income 3 & $\begin{array}{c}1.775^{* * *} \\
(0.12)\end{array}$ & $\begin{array}{c}1.178^{* * *} \\
(0.06)\end{array}$ & $\begin{array}{c}0.879 * * * \\
(0.04)\end{array}$ & $\begin{array}{c}0.854^{* * *} \\
(0.03)\end{array}$ & $\begin{array}{c}0.861^{* * *} \\
(0.03)\end{array}$ & $\begin{array}{c}1.047^{* * *} \\
(0.04)\end{array}$ \\
\hline Age & $\begin{array}{c}0.483^{* * *} \\
(0.06)\end{array}$ & $\begin{array}{c}0.146^{* * *} \\
(0.03)\end{array}$ & $\begin{array}{l}0.005 \\
(0.02)\end{array}$ & $\begin{array}{c}-0.061^{* * *} \\
(0.02)\end{array}$ & $\begin{array}{c}-0.052^{* *} \\
(0.02)\end{array}$ & $\begin{array}{c}0.110^{* * *} \\
(0.02)\end{array}$ \\
\hline $\operatorname{Age}^{2}$ & $\begin{array}{c}-0.010^{* * *} \\
(0.00)\end{array}$ & $\begin{array}{c}-0.003^{* * *} \\
(0.00)\end{array}$ & $\begin{array}{l}0.000 \\
(0.00)\end{array}$ & $\begin{array}{c}0.001^{* * *} \\
(0.00)\end{array}$ & $\begin{array}{c}0.001^{* *} \\
(0.00)\end{array}$ & $\begin{array}{c}-0.002^{* * *} \\
(0.00)\end{array}$ \\
\hline $\mathrm{Age}^{3}$ & $\begin{array}{c}0.000^{* * *} \\
(0.00)\end{array}$ & $\begin{array}{c}0.00 *^{*} \\
(0.00)\end{array}$ & $\begin{array}{c}-0.000^{*} \\
(0.00)\end{array}$ & $\begin{array}{c}-0.000^{* * *} \\
(0.00)\end{array}$ & $\begin{array}{c}-0.000^{* * *} \\
(0.00)\end{array}$ & $\begin{array}{c}0.000^{* * *} \\
(0.00)\end{array}$ \\
\hline Education (High School) & $\begin{array}{c}0.373^{* * *} \\
(0.06)\end{array}$ & $\begin{array}{c}0.134^{* * *} \\
(0.03)\end{array}$ & $\begin{array}{l}0.029 \\
(0.02)\end{array}$ & $\begin{array}{c}-0.013 \\
(0.01)\end{array}$ & $\begin{array}{l}0.005 \\
(0.01)\end{array}$ & $\begin{array}{c}0.108^{* * *} \\
(0.01)\end{array}$ \\
\hline Education (University) & $\begin{array}{l}0.043 \\
(0.04)\end{array}$ & $\begin{array}{c}0.129 * * * \\
(0.02)\end{array}$ & $\begin{array}{c}0.150^{* * *} \\
(0.01)\end{array}$ & $\begin{array}{c}0.150^{* * *} \\
(0.01)\end{array}$ & $\begin{array}{c}0.152^{* * *} \\
(0.01)\end{array}$ & $\begin{array}{c}0.137^{* * *} \\
(0.01)\end{array}$ \\
\hline Business Owner & $\begin{array}{c}0.564^{* * *} \\
(0.07)\end{array}$ & $\begin{array}{c}0.181^{* * *} \\
(0.03)\end{array}$ & $\begin{array}{c}0.079^{* * *} \\
(0.02)\end{array}$ & $\begin{array}{c}0.072^{* * *} \\
(0.01)\end{array}$ & $\begin{array}{c}0.131^{* * *} \\
(0.02)\end{array}$ & $\begin{array}{c}0.223^{* * *} \\
(0.01)\end{array}$ \\
\hline Adults & $\begin{array}{c}0.164^{* * *} \\
(0.03)\end{array}$ & $\begin{array}{l}0.023 \\
(0.01)\end{array}$ & $\begin{array}{c}-0.004 \\
(0.01)\end{array}$ & $\begin{array}{l}0.006 \\
(0.01)\end{array}$ & $\begin{array}{c}0.030^{* * *} \\
(0.01)\end{array}$ & $\begin{array}{c}0.040^{* * *} \\
(0.01)\end{array}$ \\
\hline Labour Productivity & $\begin{array}{l}0.252 \\
(0.19)\end{array}$ & $\begin{array}{c}0.266^{* *} \\
(0.10)\end{array}$ & $\begin{array}{c}0.196^{* * *} \\
(0.06)\end{array}$ & $\begin{array}{c}0.188^{* * *} \\
(0.05)\end{array}$ & $\begin{array}{c}0.212^{* * *} \\
(0.05)\end{array}$ & $\begin{array}{c}0.221^{* * *} \\
\quad(0.07)\end{array}$ \\
\hline Unemployment & $\begin{array}{l}-0.003 \\
(0.01)\end{array}$ & $\begin{array}{c}-0.014^{* *} \\
(0.01)\end{array}$ & $\begin{array}{c}-0.021^{* * *} \\
(0.00)\end{array}$ & $\begin{array}{c}-0.015^{* * *} \\
(0.00)\end{array}$ & $\begin{array}{c}-0.014^{* * *} \\
(0.00)\end{array}$ & $\begin{array}{c}-0.015^{* * *} \\
(0.00)\end{array}$ \\
\hline Constant & $\begin{array}{c}-5.826^{* * *} \\
(1.41)\end{array}$ & $\begin{array}{l}0.223 \\
(0.71)\end{array}$ & $\begin{array}{c}3.297^{* * *} \\
(0.45)\end{array}$ & $\begin{array}{c}4.784^{* * *} \\
(0.35)\end{array}$ & $\begin{array}{c}5.266^{* * *} \\
(0.38)\end{array}$ & $\begin{array}{c}2.688^{* * *} \\
(0.38)\end{array}$ \\
\hline Obs. & 110,253 & 110,253 & 110,253 & 110,253 & 110,253 & 110,253 \\
\hline Uncensored Obs. & 77,315 & 77,315 & 77,315 & 77,315 & 77,315 & 77,315 \\
\hline
\end{tabular}

Note: House prices and regional labour productivity are in logs. Income 1 is a dummy variable for those households whose income the previous year was between $\$ 35,000$ and $\$ 49,999$. Income 2 is a dummy for those with incomes between $\$ 50,000$ and $\$ 99,999$, and Income 3 is a dummy for those with incomes exceeding $\$ 100,000$. The reference group for income are those households who earned less than $\$ 35,000$ in the previous year. Education (High School) is a dummy for those who have a high school diploma, and Education (University) is a dummy for those who have a university degree. The reference group for education are those who have not completed high school. Each specification includes quarterly time dummies, month dummies, and age cohort dummies. Both the quantile and mean regressions account for selection (only those with positive debt are included in the outcome regressions) and the reported point estimates are unadjusted, meaning they apply only to those with positive debt.

*** Significant at the $1 \%$ level; ** significant at the $5 \%$ level; * significant at the $10 \%$ level.

mean regression results indicate that a one percentage point increase in the growth rate of house prices is associated with a 0.171 percent decrease in household total debt. We present these results for comparison purposes, but urge caution in their interpretation, because we cannot track changes 
in homeownership status over the period the growth rate spans, which may affect our parameter estimates.

\subsection{Non-Mortgage Debt}

We now turn our attention to the relationship between house prices and non-mortgage debt. Nonmortgage debt can directly be used for a number of purposes, including consumption and portfolio rebalancing, and if we can establish a relationship between house prices and non-mortgage debt, we will be able to say something meaningful about the link between consumption and housing prices.

We consider the following baseline regression model:

$$
d e b t_{i k t}^{n m}=\beta_{0}+\beta_{r} r_{t}+\beta_{p} p_{k t}+\beta_{y} y_{i t}+\beta_{x} X_{i t}+\beta_{z} Z_{k t}+\sum_{t=2}^{T} \beta_{t} d_{t}+\epsilon_{i k t}
$$

where $d e b t_{i k t}^{n m}$ is the log of outstanding non-mortgage debt of household $i$ in region $k$ at time $t$. The set of regressors is the same as in (1) and we use mean regression to estimate the relationship between non-mortgage debt and the set of regressors. As with the total mortage debt regressions, we control for selection using the Heckman selection correction model and report the unadjusted point estimates, meaning that the results apply only to those with positive non-mortgage debt. The estimates of (2) are presented in Table 4 with four specifications. ${ }^{31}$

Column I presents the results without a dummy for homeowners. The coefficient of interest is that on house prices, with an estimate of 0.254 that is statistically significant at the $1 \%$ level. This implies that a one percent increase in house prices is associated with a 0.25 percent increase in non-mortgage debt. In column II, we include a dummy for homeownership and find that the coefficient does not change much (0.264). In columns I and II, the point estimate for house prices captures the overall association between house prices and non-mortgage debt for homeowners and renters, alike. However, we know that there are different channels through which house prices affect homeowners and renters. For this reason, in column III, we introduce an interaction term between house prices and the homeownership dummy. The estimate on the house price term captures the

\footnotetext{
${ }^{31}$ To test whether the results are being influenced by outliers, we ran all of our non-mortgage debt regressions using median regression and found that the results differed little from the OLS regressions. Therefore, the results are likely not influenced by top coding. An examination of the individual debt components revealed that very few households report outstanding loans, leases and lines of credit of $\$ 500,000$ or more. For example, in 2007 there is only one household that reports having an outstanding balance on a line of credit of $\$ 500,000$ or more.
} 
Table 4: Non-Mortgage Debt Regression Results (with House Price Level)

\begin{tabular}{|c|c|c|c|c|}
\hline & I & II & III & IV \\
\hline Interest Rate & $\begin{array}{l}-0.022 \\
(0.02)\end{array}$ & $\begin{array}{c}-0.023 \\
(0.02)\end{array}$ & $\begin{array}{l}-0.023 \\
(0.02)\end{array}$ & $\begin{array}{l}-0.022 \\
(0.02)\end{array}$ \\
\hline Income 1 & $\begin{array}{l}0.030 \\
(0.03)\end{array}$ & $\begin{array}{l}0.017 \\
(0.03)\end{array}$ & $\begin{array}{l}0.021 \\
(0.03)\end{array}$ & $\begin{array}{c}0.023 \\
(0.03)\end{array}$ \\
\hline Income 2 & $\begin{array}{c}0.317^{* * *} \\
(0.04)\end{array}$ & $\begin{array}{c}0.299^{* * *} \\
(0.04)\end{array}$ & $\begin{array}{c}0.292^{* * *} \\
(0.04)\end{array}$ & $\begin{array}{c}0.291^{* * *} \\
(0.04)\end{array}$ \\
\hline Income 3 & $\begin{array}{c}0.751^{* * *} \\
(0.06)\end{array}$ & $\begin{array}{c}0.731^{* * *} \\
(0.06)\end{array}$ & $\begin{array}{c}0.718^{* * *} \\
(0.06)\end{array}$ & $\begin{array}{c}0.715^{* * *} \\
(0.06)\end{array}$ \\
\hline Age & $\begin{array}{l}-0.040 \\
(0.03)\end{array}$ & $\begin{array}{l}-0.047 \\
(0.03)\end{array}$ & $\begin{array}{c}-0.032 \\
(0.03)\end{array}$ & $\begin{array}{l}-0.061 \\
(0.03)\end{array}$ \\
\hline $\operatorname{Age}^{2}$ & $\begin{array}{l}0.001 \\
(0.00)\end{array}$ & $\begin{array}{l}0.001^{*} \\
(0.00)\end{array}$ & $\begin{array}{c}0.001 \\
(0.00)\end{array}$ & $\begin{array}{l}0.001^{*} \\
(0.00)\end{array}$ \\
\hline $\operatorname{Age}^{3}$ & $\begin{array}{r}-0.000 \\
(0.00)\end{array}$ & $\begin{array}{r}-0.000 \\
(0.00)\end{array}$ & $\begin{array}{r}-0.000 \\
(0.00)\end{array}$ & $\begin{array}{r}-0.000 \\
(0.00)\end{array}$ \\
\hline Education (High School) & $\begin{array}{l}-0.053 \\
(0.03)\end{array}$ & $\begin{array}{l}-0.051 \\
(0.03)\end{array}$ & $\begin{array}{c}-0.053^{*} \\
(0.03)\end{array}$ & $\begin{array}{c}-0.056^{*} \\
(0.03)\end{array}$ \\
\hline Education (University) & $\begin{array}{c}0.109^{* * *} \\
(0.02)\end{array}$ & $\begin{array}{c}0.113^{* * *} \\
(0.02)\end{array}$ & $\begin{array}{c}0.109^{* * *} \\
(0.02)\end{array}$ & $\begin{array}{c}0.108^{* * *} \\
(0.02)\end{array}$ \\
\hline Business Owner & $\begin{array}{c}0.082^{* *} \\
(0.03)\end{array}$ & $\begin{array}{c}0.078^{* *} \\
(0.03)\end{array}$ & $\begin{array}{c}0.078^{* *} \\
(0.03)\end{array}$ & $\begin{array}{c}0.079^{* *} \\
(0.03)\end{array}$ \\
\hline Adults & $\begin{array}{c}-0.003 \\
(0.01)\end{array}$ & $\begin{array}{r}-0.008 \\
(0.01)\end{array}$ & $\begin{array}{l}-0.008 \\
(0.01)\end{array}$ & $\begin{array}{l}-0.008 \\
(0.01)\end{array}$ \\
\hline Labour Productivity & $\begin{array}{l}0.181 \\
(0.11)\end{array}$ & $\begin{array}{l}0.170 \\
(0.11)\end{array}$ & $\begin{array}{l}0.143 \\
(0.11)\end{array}$ & $\begin{array}{l}0.158 \\
(0.11)\end{array}$ \\
\hline Unemployment & $\begin{array}{c}-0.025^{* * *} \\
(0.01)\end{array}$ & $\begin{array}{c}-0.025^{* * *} \\
(0.01)\end{array}$ & $\begin{array}{c}-0.025^{* * *} \\
(0.01)\end{array}$ & $\begin{array}{c}-0.024^{* * *} \\
(0.01)\end{array}$ \\
\hline House Price & $\begin{array}{c}0.254^{* * *} \\
(0.04)\end{array}$ & $\begin{array}{c}0.264^{* * *} \\
(0.04)\end{array}$ & $\begin{array}{l}0.017 \\
(0.06)\end{array}$ & $\begin{array}{l}0.211^{*} \\
(0.08)\end{array}$ \\
\hline Homeowner & & $\begin{array}{c}0.079^{* *} \\
(0.03)\end{array}$ & $\begin{array}{c}-4.080^{* * *} \\
(0.79)\end{array}$ & $\begin{array}{c}-0.769 \\
(0.93)\end{array}$ \\
\hline House Price $*$ Homeowner & & & $\begin{array}{c}0.345^{* * *} \\
(0.07)\end{array}$ & \\
\hline Constant & $\begin{array}{c}7.044^{* * *} \\
(0.65)\end{array}$ & $\begin{array}{c}7.061^{* * *} \\
(0.65)\end{array}$ & $\begin{array}{c}9.922^{* * *} \\
(0.86)\end{array}$ & $\begin{array}{c}7.985^{* * *} \\
(1.05)\end{array}$ \\
\hline \multicolumn{5}{|c|}{ Combined effects of house prices on homeowners of different age groups } \\
\hline Age 18-35 & & & & $0.278^{* * *}$ \\
\hline Age $36-55$ & & & & $0.402^{* * *}$ \\
\hline Age $56+$ & & & & $0.339^{* * *}$ \\
\hline $\begin{array}{l}\text { Obs. } \\
\text { Uncensored Obs. }\end{array}$ & $\begin{array}{c}110,253 \\
54,970\end{array}$ & $\begin{array}{c}110,253 \\
54,970\end{array}$ & $\begin{array}{c}110,253 \\
54,970\end{array}$ & $\begin{array}{c}110,253 \\
54,970\end{array}$ \\
\hline
\end{tabular}

Note: Income 1 is a dummy variable for those households whose income the previous year was between $\$ 35,000$ and $\$ 49,999$. Income 2 is a dummy for those with incomes between $\$ 50,000$ and $\$ 99,999$, and Income 3 is a dummy for those with incomes exceeding $\$ 100,000$. The reference group for income are those households who earned less than $\$ 35,000$ in the previous year. Education (High School) is a dummy for those who have a high school diploma, and Education (University) is a dummy for those who have a university degree. The reference group for education are those who have not completed high school. Each specification includes quarterly time dummies, month dummies, and age cohort dummies. The errors are clustered at the forward sortation area level (this is based on the first three digits of the area code-there are 1614 forward sortation areas). The combined effects of house prices on homeowners of different age groups sum up all the interaction terms pertaining to house prices, and regression IV includes all necessary interaction terms (but not all are reported). The mean regressions account for selection (only those with positive non-mortgage debt are included in the outcome regressions) and the reported point estimates are unadjusted, meaning they apply only to those with positive non-mortgage debt.

*** Significant at the $1 \%$ level; ${ }^{* *}$ significant at the $5 \%$ level; $*$ significant at the $10 \%$ level. 
effect of house prices on the non-mortgage debt of renters, and we see that the coefficient estimate is not statistically significant. However, for homeowners, a one percent increase in house prices is associated with a $0.362(0.017+0.345)$ increase in non-mortgage debt. An F-test reveals that the house price and interaction terms are jointly significant at the $1 \%$ level.

As mentioned above, homeowners are heterogeneous and the interaction term groups together two distinct types of homeowners - established homeowners with enough equity in their homes to access HELOCs, ${ }^{32}$ and recent homeowners who have less capacity to access HELOCs and sometimes rely more on other types of secured and unsecured borrowing (i.e. non-home equity-based borrowing) for external financing. We address this heterogeneity in column IV by interacting house prices and dummies for homeowners of different ages. That is, we interact house prices with dummies for young homeowners (those whose household head is between the ages 18 and 35, inclusive), middle-aged homeowners (36 to 55), and older homeowners (56+). In analyzing the combined point estimates for the effects of house prices for all three age groups, we find that the coefficient on young homeowners is 0.278 and is significant at the $1 \%$ level. The same estimates for middle-aged and older homeowners are 0.402 and 0.339 , respectively, and both are significant at the $1 \%$ level. T-tests suggest that while the point estimate for young homeowners is statistically different from both the estimates for middle-aged and older homeowners, those of middle-age and older homeowner are not statistically different from one another. The larger coefficients on the middle-aged and older households likely reflect these households' ability to borrow against equity in their homes and are evidence of a wealth effect.

Without valid instruments, we are unable to identify a causal relationship between house prices and non-mortgage debt. It is possible that causality runs in the other direction- the ability of households to take on more debt over the sample period led to the bidding up of house prices - or that there are feedback effects between the two variables. Although it is possible that the rise in non-mortgage debt, and in particular that used to purchase a residence, led, in part, to increases in house prices, it is likely that this effect will be small. To show that this is the case, we use the information in our data set about lines of credit. The CFM has always classified lines of credit as secured and unsecured. As pointed out in Crawford and Faruqui (2012), it is likely that

\footnotetext{
${ }^{32}$ Here we assume that given more favourable pricing of home-secured borrowing, a household who has a choice between this and other types of borrowing, would chose the former.
} 
these secured lines of credit are backed by housing assets. Beginning in 2005, the CFM started referring to these lines of credit explicitly as home-secured (HELOCs) with respondents reporting the purpose of their HELOCs, including a joint category for whether or not they were used to purchase a residence or a business. Using these data, we know that in 2007, only 1.3 percent of households report using a HELOC to purchase a residence or business (or alternatively, 1.9 percent of homeowners). Table 5 presents the uses of HELOCs, as well as the average outstanding balance for those that are using their HELOCs. ${ }^{33}$ We see that the average household that has outstanding

\begin{tabular}{|c|c|c|}
\hline & Amount & $\begin{array}{c}\% \text { of Total } \\
\text { HELOCs }\end{array}$ \\
\hline Consumption & 6,604 & 16.7 \\
\hline Housing Investment & 3,494 & 8.9 \\
\hline Debt Repayment & 9,685 & 24.6 \\
\hline Investment & 13,333 & 33.7 \\
\hline Purchase of Residence/Business & $(5,622)$ & $(14.2)$ \\
\hline Other & 6,386 & 16.2 \\
\hline Total Outstanding HELOCs & 39,502 & 100.0 \\
\hline
\end{tabular}

debt on their HELOC has $\$ 39,502$ outstanding, out of which $\$ 5,622$ (or 14.2 percent) was used for the purchase of a residence or business. ${ }^{34}$ This is less than the amount used for consumption (16.7 percent), debt repayment (24.6 percent) and other investment (19.5 percent). Given these numbers, it is possible that households' ability to take on debt through instruments like HELOCs influenced house prices, but this effect is probably small.

As with the total debt regressions, in Table D2 (Appendix D) we present the results for nonmortgage debt using the quarter-over-quarter annual growth rate of regional house prices house instead of the level of house prices. The combined house price and interaction term in column III is not statistically significant and therefore the growth model does not find a relationship between changes in the growth rate of house prices and non-mortgage debt. ${ }^{35}$

\footnotetext{
${ }^{33}$ We refer to those with outstanding balances on the HELOCs as those who are using their HELOCs to distinguish them from those who may have a HELOC, but have a zero balance on it.

${ }^{34}$ For the 1.3 percent of households that report using a HELOC to purchase a residence or business, the average amount borrowed was $\$ 69,361$.

${ }^{35}$ Again, we urge caution in the interpretation of these results given that we cannot track changes in homeownership status over the period the growth rate spans.
} 


\section{$5 \quad$ House Prices and Real Outlays}

In this section, we begin by analyzing how debt is used, with a focus on the behaviour of different types of households. We then examine the relationship between house prices and consumption given the relationship between house prices and debt estimated in the previous section.

\subsection{Uses of Household Debt}

For households with debt (both homeowners and renters), the CFM provides information on the purposes of the debt, with details for each debt instrument. Survey respondents are asked to choose from an extensive list of debt uses which we condense to a list of five possible categories: consumption, ${ }^{36}$ housing investment, ${ }^{37}$ other investment, debt repayment, and other uses (see Table 6 for a detailed list of what is included in each of these categories). We can further group housing investment, other investment, and debt repayment into a portfolio improvement/rebalancing category. ${ }^{38}$ Theory predicts that households who use debt for consumption are either liquidity constrained, or unconstrained, but do not care about future bequests and want to consume unexpected house price increases. Moreover, households who use debt for portfolio rebalancing purposes are more likely to be unconstrained.

We first characterize average amounts of non-mortgage debt used for different purposes in Table 7 for selected years. Over the entire sample period, households used an average of 44.4 percent of non-mortgage debt for consumption. And while the percentage of non-mortgage debt used to finance consumption decreased from 48.4 percent in 1999 to 43.9 percent in 2007, outstanding nonmortgage debt increased by $\$ 2,311(\$ 11,408-\$ 9,097)$, and as a result the amount of debt used to finance consumption increased by almost fourteen percent (to $\$ 5,008$ from $\$ 4,405$ ).

\footnotetext{
${ }^{36}$ As mentioned earlier, mortgage debt directly finances future housing services consumption, which is part of total household consumption. At the same time, other forms of home-based debt, such as mortgage refinancing and home equity debt, may also be financing housing services consumption indirectly, by allowing households to stay in their homes. We do not have a way of measuring housing services consumption financed from these sources, and therefore it is not included in our measure of consumption. Given that our measure of consumption does not include an explicit measure of housing services, it may be better understood as consumption of non-housing services.

${ }^{37}$ We include seventy percent of debt used for home improvement in consumption based on the findings in the Canadian Mortgage and Housing Corporation (CMHC) Renovation and Home Purchase Report (2010). A survey finds that among homeowner households that renovated in 2009, roughly seventy percent completed some form of alteration and improvement of their home. From this number, we assume that seventy percent of reported home improvement is actual alteration or improvement - and hence categorized as housing investment - and thirty percent is maintenance and repair-and categorized as consumption.

${ }^{38}$ Note that housing investment may lead to increases in housing consumption, so we use the term "portfolio improvement/rebalancing" with this caveat.
} 
Table 6: Debt Usage Categories

\begin{tabular}{|c|c|c|c|c|}
\hline Consumption & $\begin{array}{l}\text { Housing } \\
\text { Investment }\end{array}$ & Debt Repayment & Other Investment & Other Uses \\
\hline $\begin{array}{l}\text { Purchase of motor } \\
\text { vehicle } \\
\text { - Purchase of computer } \\
\text { - Vacation } \\
\text { - Student loan } \\
\text { - Living expenses } \\
\text { - Other current } \\
\text { spending } \\
\text { - Other not for } \\
\text { current spending } \\
\text { - Purchase big ticket } \\
\text { item } \\
0.3^{*} \text { Home improvement }\end{array}$ & $\begin{array}{l}0.7^{*} \text { Home } \\
\text { improvement }\end{array}$ & $\begin{array}{l}\text { Pay off another loan } \\
\text { Pay off general debt }\end{array}$ & $\begin{array}{l}\text { - General investment } \\
\text { - Purchase of } \\
\text { residence/business } \\
\text {. Purchase of RRSP } \\
\text {. Other investments }\end{array}$ & . Other \\
\hline
\end{tabular}

Note: We assign thirty percent of home improvement to consumption and seventy percent to housing investment based on the findings in the Renovation and Home Purchase Report by Canadian Mortgage and Housing Corporation (CMHC). This definition of consumption and its broad categories is different than the one used in Bailliu, Kartashova and Meh (2012). The items listed under the five categories encompass the list of possible purposes provided in the CFM.

Table 7: Uses of Outstanding Non-Mortgage Debt by Homeowners and All Households

\begin{tabular}{|c|c|c|c|c|c|c|c|c|}
\hline & \multicolumn{2}{|c|}{1999} & \multicolumn{2}{|c|}{2003} & \multicolumn{2}{|c|}{2007} & \multicolumn{2}{|c|}{ 1999-2007 } \\
\hline & Owners & Total & Owners & Total & Owners & Total & Owners & Total \\
\hline$\%$ of Non-Mortgage $\mathrm{D}$ & & & & & & & & \\
\hline $\begin{array}{l}\text { Consumption } \\
\text { (\$ value) }\end{array}$ & $\begin{array}{c}44.1 \\
(4,946)\end{array}$ & $\begin{array}{c}48.4 \\
(4,405)\end{array}$ & $\begin{array}{c}43.2 \\
(5,187)\end{array}$ & $\begin{array}{c}45.5 \\
(4,605)\end{array}$ & $\begin{array}{c}40.1 \\
(5,663)\end{array}$ & $\begin{array}{c}43.9 \\
(5,008)\end{array}$ & $\begin{array}{c}40.4 \\
(5,262)\end{array}$ & $\begin{array}{c}44.4 \\
(4,697)\end{array}$ \\
\hline Housing Investment & 4.5 & 3.8 & 5.1 & 4.6 & 6.2 & 5.3 & 5.2 & 4.6 \\
\hline Debt Repayment & 19.3 & 18.7 & 19.9 & 19.6 & 19.7 & 19.0 & 20.1 & 19.7 \\
\hline Investment & 17.5 & 15.3 & 16.5 & 15.4 & 20.9 & 18.4 & 18.9 & 16.9 \\
\hline Other & 14.7 & 13.7 & 15.3 & 14.9 & 14.4 & 13.3 & 15.1 & 14.4 \\
\hline Non-Mortgage Debt & 11,208 & 9,097 & 12,004 & 10,129 & 14,138 & 11,408 & 13,089 & 10,631 \\
\hline Mortgage Debt & 48,290 & 32,427 & 45,162 & 33,851 & 49,796 & 34,191 & 47,723 & 33,056 \\
\hline Total Debt & 61,466 & 43,393 & 59,244 & 45,954 & 66,401 & 47,774 & 62,979 & 45,736 \\
\hline
\end{tabular}

Note: All dollar values are in 2002 quarter 1 dollars. Homeowners are households that report that they own real estate. Due to top coding (we set the highest debt level a household can report for a single debt instrument is $\$ 500,000$ ), our estimates for total and mortgage debt likely underestimate the true values and changes over time.

Homeowners, on average, carry much more total debt than those who rent. This is in large part due to the fact that homeowners have mortgages, which are by far the largest component of household debt. Moreover, the amount of debt these homeowners carry and the way they use it likely varies across different age groups. Table 8 presents the uses of outstanding non-mortgage debt by age of homeowners for 1999 and 2007, along with outstanding non-mortgage, credit card, mortgage and total debt.

The non-mortgage debt of home owners is highest for the middle-aged group in both 1999 and 2007. At the same time, the proportion of outstanding non-mortgage debt used for consumption declines as homeowners age. In 2007, young homeowners report using an average of 51 percent of outstanding non-mortgage debt for consumption. In the same year, older homeowners report using 33 percent of non-mortgage debt for consumption with the remainder used largely for portfolio 
Table 8: Uses of Outstanding Non-Mortgage Debt of Homeowners by Age

\begin{tabular}{l|c|c|c}
1999 & Young & Middle-Aged & Older \\
\hline \% of Non-Mortgage Debt used for: & & & \\
Consumption & 53.1 & 42.0 & 35.3 \\
Housing Investment & 3.8 & 5.0 & 3.2 \\
Debt Repayment & 21.4 & 18.6 & 17.8 \\
Investment & 10.3 & 18.6 & 26.8 \\
Other & 11.3 & 15.7 & 16.8 \\
\hline Non-Mortgage Debt & 12,208 & 13,975 & 5,758 \\
Credit/Charge Card Debt & 2,365 & 2,199 & 1,228 \\
Mortgage Debt & 79,516 & 51,437 & 15,042 \\
Total Debt & 94,090 & 67,613 & 22,029 \\
\hline \hline & & & \\
2007 & Young & Middle-Aged & Older \\
\hline \% of Non-Mortgage Debt used for: & & & \\
Consumption & 51.0 & 39.4 & 33.1 \\
Housing Investment & 5.0 & 6.3 & 6.5 \\
Debt Repayment & 25.6 & 19.0 & 16.8 \\
Investment & 9.1 & 21.8 & 24.7 \\
Other & 9.3 & 13.5 & 18.9 \\
\hline Non-Mortgage Debt & 13,510 & 18,698 & 9,443 \\
Credit/Charge Card Debt & 2,753 & 2,919 & 1,335 \\
Mortgage Debt & 103,440 & 60,594 & 14,389 \\
Total Debt & 119,705 & 82,212 & 25,168 \\
Note: All & & &
\end{tabular}

Note: All dollar values are in 2002 quarter 1 dollars. Young households are those whose household head is between the ages of 18 and 35 (inclusive). Middle-aged households have a household head between 36 and 55 (inclusive), and older households have heads that are 56 and older. Due to top coding (we set the highest debt level a household can report for a single debt instrument is $\$ 500,000$ ), our estimates for total debt likely underestimate the true values.

improvement purposes (excluding "other uses").

Here, the age of homeowners can be used as an indicator for whether or not households who use debt to finance consumption may be constrained. As discussed earlier, for a household who is a recent homeowner and therefore more likely to be young, taking any equity out of his/her home to smooth consumption may be costly (as in the case of loan-to-value ratios of above twenty percent) in the absence of the boost to their equity through house price increases, with the cost potentially exceeding the benefits. However, house price increases may lower the costs (either eliminating the need for mortgage insurance or lowering the premium) and allow otherwise liquidity constrained households to take out equity and consume. ${ }^{39}$ At the same time, older households with large amounts of equity, who are unconstrained, may choose to consume house price increases if these increases are unexpected and homeowners are not altruistic (do not value bequests). Middle-aged

\footnotetext{
${ }^{39}$ Since 2011, non-amortizing HELOCs have not been eligible for mortgage insurance, which was not the case during our sample period.
} 
unconstrained households would also take out home equity for portfolio improvement purposes

both on the asset and debt side, such as reinvesting housing wealth into financial assets, and restructuring household debt to reduce the costs of its servicing. However, as shown in Table 8, portfolio improvement is not limited to older and middle-aged households only.

Most non-mortgage debt in this exercise is home equity debt consisting of home equity lines of credit and home equity loans. As mentioned earlier, for our purposes it would be ideal to have information on mortgage refinancing for this period as well. The reason why including these data may be desirable is that mortgage refinancing allows households to have much less equity in their homes compared to home equity debt. The CFM only started including questions on this method of home equity extraction in 2007 (see Appendix C for more information on mortgage refinancing in 2007). However, we can still use this one year of data to help us distinguish between different types of constrained and unconstrained households in addition to what has been done above. In Canada, during our sample period, home equity lines of credit are available to households with at least twenty percent of equity in the home (i.e. the total of the mortgage balance outstanding and the limit on the home line of credit must be within eighty percent of the value of the home). Unlike households with less than twenty percent in equity or borrowing in excess of eighty percent loan-to-value ratio, in 2007 these households did not incur additional costs of taking out home equity such as mortgage insurance. As a result, we think that households who go from below eighty percent LTV on their home-based debt to above eighty percent LTV, and pay mortgage insurance to consume equity take-out, are constrained.

\subsection{House prices, debt and consumption}

Finally, in what follows, we directly examine the link between debt and consumption andcombining this with our estimates from the previous section - the link between house prices, debt and consumption. For the aggregates, we do this using some simple back-of-the-envelope calculations based on national house prices and annual data. From 1999 to 2007, national house prices in Canada increased by 52 percent. We know from the previous section that house prices were associated with homeowner non-mortgage debt, but not that of renters. The results from column III of Table 4 show that a one percent increase in house prices is associated with a 0.362 percent increase in the outstanding non-mortgage debt of homeowners. This implies that the 52 percent increase 
in national house prices was associated with a 18.82 percent $(52 \times 0.362)$ increase in outstanding non-mortgage debt of homeowners.

In 1999, the average homeowner had $\$ 11,208$ in outstanding non-mortgage debt (Table 7$).{ }^{40}$ If we were to predict homeowner outstanding non-mortgage debt for 2007 based on house prices only, expected non-mortgage debt would be $\$ 13,317$ (\$11,208 x 1.1882), an increase of $\$ 2,109$. From Table 7, we also know that on average 40.4 percent of homeowner non-mortgage debt was used for consumption, implying that roughly $\$ 852$ out of the $\$ 2,109$ increase in outstanding non-mortgage debt was used for consumption.

To put these numbers in perspective, we compare them to the net flow of homeowner nonmortgage debt over the sample period. By 2007, actual outstanding homeowner debt stood at $\$ 14,138$ - an increase of $\$ 2,930$ over 1999 . This $\$ 2,930$ is the net flow of non-mortgage debt for homeowners, and includes originations less repayments over the sample period. ${ }^{41}$ With this, we can see that house prices were associated with 72.0 percent $(\$ 2,109 / \$ 2,930)$ of the net flow of homeowner non-mortgage debt over the sample period. Furthermore, 29.1 percent $(\$ 852 / \$ 2,930)$ of the net flow of homeowner non-mortgage debt was associated with the increase in house prices and used for consumption.

We can calculate similar numbers for the entire Canadian household sector. In the CFM, homeowners (defined here as anyone who owns real estate) account for 67 percent of households in 1999 and 69 percent in 2007. Therefore, homeowners contributed approximately $\$ 1,434(\$ 2,109$ $\mathrm{x}$ 0.68) to the increase in average household non-mortgage debt, which represents 62.1 percent of the net flow of non-mortgage debt for all households over the sample period (the net flow of nonmortgage debt for all households was $\$ 2,311(\$ 11,408-\$ 9,097)$ over the sample period - see Table 1). And again, given that on homeowners used an average 40.4 percent of non-mortgage debt for consumption, we can say that $\$ 579$ of the $\$ 1,434$ was used for consumption. Thus, 25.1 percent of the net flow of total non-mortgage debt was associated with the increase in house prices and used for consumption. ${ }^{42}$

\footnotetext{
${ }^{40}$ Note that this number, $\$ 11,208$, includes homeowners with zero non-mortgage debt. Homeowners with positive non-mortgage debt account for about 36 percent of households and have an average outstanding non-mortgage debt balance of $\$ 20,666$ in 1999 and $\$ 27,567$ in 2007 .

${ }^{41}$ The net flow of debt is the change in outstanding debt over a period of time. We are unable to distinguish originations (new debt) from debt repayment and therefore cannot identify the flow of new debt. We are not aware of any micro and macro data set that reports debt flows, net of repayments - that is, originations only.

${ }^{42} \mathrm{Up}$ to this point, the literature has focused on the connection between house prices and consumption. However,
} 
It is important to qualify these results in two ways. First, it should be noted that the percentage of non-mortgage debt used for consumption may have been underestimated since some of the debt used for debt repayment may have been used originally for consumption, and therefore should be counted in the consumption category. ${ }^{43}$ We included "debt repayment" as a debt use category because we do not know what the debt was used for originally. However, we could reset the shares of each of the other four categories by eliminating the "debt repayment" category and then determining the new set of shares (implicitly assuming the original use of the debt in the "debt repayment" category was used for the other four remaining categories in the same proportions as the reported purposes). If we were to do this, consumption would account for 50.8 percent of homeowner debt usage, meaning that for the entire Canadian household sector, the increase in house prices from 1999 to 2007 would be associated with a $\$ 728$ (as opposed to $\$ 579$ ) increase in non-mortgage debt used for consumption, which represents 31.5 percent of the net flow of non-mortgage debt.

The second qualification pertains to the relationship between our results and the connection between house prices and aggregate consumption (as defined in the Canadian System of National Accounts). Measures of aggregate consumption include housing consumption, which is normally calculated by adding together total rents paid by non-homeowners and imputed rents of homeowners, which is calculated by applying a quality adjustment coefficient to average rents. We do not have the data to create a household-level variable and therefore do not include housing consumption in our definition of consumption. Our results are important in the establishment of a relationship between house prices, debt and consumption. However, they can also be thought of as a conservative lower bound for the relationship between house prices and aggregate consumption, assuming that the relationship would be stronger if housing consumption were included in our analysis.

the focus on consumption will understate the total impact of the financial accelerator channel since it does not consider home renovations, and hence overall household spending. If we combine consumption and housing investment from the debt uses table, we see that these categories together account for 45.6 percent of debt usage for homeowners, meaning $\$ 962$ of the $\$ 2,109$ increase in non-mortgage debt associated with house prices increases was used for consumption and housing investment (the number for consumption alone is $\$ 852$ ). We have presented the data and our results in such a way that it is easy for the reader to do their own calculations.

${ }^{43}$ Note that the debt repayment category may include the repayment of debt that was originally incurred to finance one of the other four categories. If this is true, debt repayment will not contribute to an increase in non-mortgage debt. However, we do not know what the original debt was used for. Moreover, if debt was used to pay off mortgage debt, this would contribute to an increase in non-mortgage debt, but again we cannot identify the original use of the debt. It is for this reason that we include "debt repayment" as its own category. It is also possible that debt repayment will contribute to consumption, housing investment, other investment and other uses indirectly by allowing household to spread debt repayment over a longer period of time or repay debt at lower interest rates. In both cases, this would free up cash for current real outlays. 


\section{Conclusions}

In this paper we have used Canadian household-level data to estimate the relationship between house prices and household non-mortgage (consumer) debt, and then used these results to better understand the relationship between house prices and non-housing consumption. As noted in section 1, our paper is related to recent work at the Bank of Canada by Bailliu, Kartashova and Meh (BKM, 2012) and Crawford and Faruqui (2012). And though the findings in this paper are generally in line with BKM and Crawford and Faruqui, due to differences in variable definitions and data calculations, the reported results and statistics in this paper should not be directly compared with these recent papers.

In this paper, we find that house prices are positively associated with the non-mortgage debt of homeowners. More specifically, the joint point estimate for homeowners is 0.36 , controlling for interest rates, household income, and other demographic and region-specific variables. Moreover, we find a positive and statistically significant relationship between house prices and non-mortgage debt for homeowners of all ages, but the relationship is stronger for those homeowners above 35 years old. Based on our estimates, we determine that increases in house prices over the 1999-2007 period accounted for 62.1 percent of the net flow of non-mortgage debt.

In addition to reporting outstanding debt balances, the survey data we use also provides the purpose for which the debt was undertaken by households. From this, we are able to connect nonmortgage debt to non-housing consumption, and given our estimates of the relationship between house prices and non-mortgage debt, we can make direct inferences on the relationship between house prices and debt-financed non-housing consumption. In the data, we find that about forty percent of homeowner non-mortgage debt is used for non-housing consumption, which implies that about 25.1 percent of the net flow of non-mortgage debt was related to house prices and used for non-housing consumption (across all households). Due to the fact that our definition of consumption does not include housing consumption and our definition of non-mortgage debt does not include mortgage refinancing, our results can be thought of as the establishment of a conservative lower bound for the relationship between house prices and aggregate consumption. 


\section{References}

Allen, J., E. Damar and D. Martinez-Miera (2012): "Consumer Bankruptcy and Information," Bank of Canada Working Paper 2012-18.

Attanasio, O., L. Blow, R. Hamilton and A. Leicester (2009): "Booms and Busts: Consumption, House Prices and Expectations," Economica 76, pp. 20-50.

Bailliu, J., K. Kartashova and C. Meh (2012): "Household Borrowing and Spending in Canada," Bank of Canada Review (Winter 2011-2012), pp. 16-29.

Bostic, R., S. Gabriel and G. Painter (2009): "Housing Wealth, Financial Wealth, and Consumption: New Evidence From Micro Data," Regional Science and Urban Economics 39, pp. 79-89.

Buchinsky, M. (1998): "Recent Advances in Quantile Regression Models: A Practical Guide for Empirical Research," Journal of Human Resources 33, pp. 88-126.

Buchinsky, M. and J. Hahn (1998): "An Alternative Estimator for the Censored Quantile Regression Model," Econometrica 66, pp. 653-671.

Campbell, J. and J. Cocco (2007): "House Do House Prices Affect Consumption? Evidence from Micro Data," Journal of Monetary Economics 54, pp. 591-621.

Crawford, A. and U. Faruqui (2012): "What Explains Trends in Household Debt in Canada?" Bank of Canada Review (Winter 2011-2012), pp. 3-15.

Dey, S., R. Djoudad and Y. Terajima (2008): "A Tool for Assessing Financial Vulnerabilities in the Household Sector," Bank of Canada Review, Summer 2008.

Dynan, K. and D. Kohn (2007): "The Rise in U.S. Household Indebtedness: Causes and Consequences," In: Kent, C. and J. Lawson (eds), The Structure and Resilience of the Financial System, Reserve Bank of Australia, Syndey.

Engelhardt, G. V. (1994): "House Prices and the Decision to Save for Down Payments," Journal of Urban Economics 36, pp. 209-237.

Faruqui, U. (2008): "Indebtedness and the Household Financial Health: An Examination of the Canadian Dent Service Ration Distribution," Bank of Canada Working Paper 2008-46.

_ (2010): "Assembling a Real-Financial Micro-Dataset for Canadian Households," Bank of Canada Working Paper 2010-6.

Faruqui, U. and S. Lai (2011): "A Tale of Two Surveys: A Comparison of the Canadian Financial Monitor (CFM) with the Survey of Financial Security," Mimeo, Bank of Canada.

Greenspan, A. and J. Kennedy (2007): "Sources and Uses of Equity Extraction from Homes," Oxford Review of Economic Policy 24(1), pp. 120-144.

Heckman, J. (1979): "Sample Selection Bias as a Specification Error," Econometrica 47, pp. 153-161.

Iacoviello, M. and M. Pavan (2009): "Housing and Debt Over the Life Cycle and Over the Business Cycle," Boston College Working Paper 723. 
Klein, R. and R. Spady (1993): "An Efficient Semiparametric Estimator of the Binary Response Model," Econometrica 61, pp. 387-421.

Koenker, R. and G. Bassett Jr. (1978): "Regression Quantiles," Econometrica 46, pp. 33-50.

Mian, A. R. and A. Sufi (2009): "House Prices, Home Equity-Based Borrowing, and the U.S. Household Leverage Crisis," NBER Working Paper 15283.

Sinai, T. and N. S. Souleles (2005): "Owner-Occupied Housing as a Hedge Against Rent Risk," Quarterly Journal of Economics 120(2), pp. 763-789.

\section{Appendix}

\section{A Quantile Regression}

While classical linear regression methods based on minimizing the sum of squared residuals allow researchers to estimate models for conditional mean functions, quantile regression (as defined in Koenker and Bassett, 1978) provides a tool for estimating models for the full range of conditional quantile functions.

Quantile regression can be defined as:

$$
y_{i t}=x_{i t}^{\prime} \beta_{\theta}+\epsilon_{\theta i t} \quad \text { with } \quad \operatorname{Quant}_{\theta}\left(y_{i t} \mid x_{i t}\right)=x_{i t}^{\prime} \beta_{\theta}
$$

where $y_{i t}$ is the dependent variable for household $i$ at time $t, x_{i t}$ is a vector of regressors, $\beta_{\theta}$ is the vector of parameters to be estimated, and $\epsilon_{\theta i t}$ is a vector of residuals. Let $Q_{\theta}\left(y_{i t} \mid x_{i t}\right)$ denote the $\theta^{\text {th }}$ regression quantile that solves the following problem:

$$
\min _{\beta} \frac{1}{n}\left\{\sum_{i, t: y_{i t} \geq x_{i t}^{\prime} \beta} \theta\left|y_{i t}-x_{i t}^{\prime} \beta\right|+\sum_{i, t: y_{i t}<x_{i t}^{\prime} \beta}(1-\theta)\left|y_{i t}-x_{i t}^{\prime} \beta\right|\right\}=\min _{\beta} \frac{1}{n} \sum_{i=1}^{n} \rho_{\theta} \epsilon_{\theta i t}
$$

where $\rho_{\theta}(\cdot)$ is defined as:

$$
\rho_{\theta}\left(\epsilon_{\theta i t}\right)= \begin{cases}\theta \epsilon_{\theta i t} & \text { if } \epsilon_{\theta i t} \geq 0 \\ (\theta-1) \epsilon_{\theta i t} & \text { if } \epsilon_{\theta i t}<0\end{cases}
$$

The minimization problem is then solved by linear programming methods. As Buchinsky (1998) points out, as one increases $\theta$ continuously from 0 to 1 , one traces the entire conditional distribution of $y$, conditional on $x$. The quantile regression coefficients can be interpreted as the partial derivative of the conditional quantile of the dependent variable $y$ with respect to a particular regressor, i.e. $\partial Q_{\theta}(y \mid x) / \partial x$. In other words, the coefficients represent the marginal change in $y$ at the $\theta^{\text {th }}$ conditional quantile due to a marginal change in the independent variable. Quantile regression avoids the restrictive assumption that the error terms are identically distributed at all points of the conditional distribution of the dependent variable, implicitly acknowledging household heterogeneity and the possibility that the estimated slope parameters vary at different quantiles of the response variable distribution.

\section{B Changes in the Housing Market}

A number of notable regulatory changes over the sample period, along with the introduction of new mortgage products, may have played a role in the increase in total household debt. Table B1 
provides a timeline for important changes in the mortgage market from 1999 to 2007.

Table B1: Important Changes in the Canadian Mortgage Market and Rules for Government-Backed Mortgage Insurance

\begin{tabular}{|l|l|}
\hline Year & Regulatory Change/Product Innovation \\
\hline 1998 & $\begin{array}{l}\text { After a pilot project for first-time homebuyers in } 1992 \text { and } \\
\text { its term extension, CMHC introduced the 95\% LTV product } \\
\text { for insured mortgages available to all home-buyers. }\end{array}$ \\
\hline 2001 & $\begin{array}{l}\text { CMHC introduces Canadian mortgage bonds, enabling the } \\
\text { securitization of mortgage debt }\end{array}$ \\
\hline 2006 & $\begin{array}{l}\text { Reduction in insurance premia for households with loan-to- } \\
\text { value ratios greater than 0.9 } \\
\text { mortgage insurance to 30, 35, and 40 years. }\end{array}$ \\
\hline 2007 & $\begin{array}{l}\text { Maximum LTV for insured mortgages increased to 100\% } \\
\text { Maximum LTV for refinancing increased to 95\% } \\
\text { New products introduced for self-employed borrowers } \\
\text { Mortgage insurance for 100\% financed rental properties } \\
\text { introduced }\end{array}$ \\
\hline
\end{tabular}

Note: Starting in 2008, a number of measures have been adopted to tighten mortgage regulations. CMHC: Canadian Mortgage and Housing Corporation

\section{Mortgage Refinancing}

Beginning in 2007, households are asked whether they refinanced their mortgage to increase the amount borrowed in the last twelve months. From their responses, we know that approximately 3.3 percent of households refinanced their mortgage (this represents 9.5 percent of all households that have outstanding mortgage debt). The respondents also report the additional amount borrowed with refinancing and the primary reason for increasing the size of their mortgage. Table C1 reports the mean amount borrowed through refinancing, as well as the percentage used for consumption, home improvement, debt repayment, investment and other uses.

Table C1: Mortgage Refinancing

\begin{tabular}{l|cc} 
& Amount & $\begin{array}{c}\text { \% of Equity } \\
\text { Extraction }\end{array}$ \\
\hline \hline Consumption & 5,046 & 10.7 \\
Housing Investment & 5,815 & 12.4 \\
Debt Repayment & 15,246 & 32.4 \\
Investment & 17,062 & 36.3 \\
Other & 3,865 & 8.2 \\
\hline Equity Extraction & 47,035 & 100.0
\end{tabular}


Conditional on having refinanced their mortgage, the average household borrowed an additional $\$ 47,035$ through refinancing, 10.7 percent of which went to consumption $(\$ 5,046)$. The vast majority of debt through refinancing was used for debt repayment and investment - combined, they accounted for 68.7 percent of mortgage refinancing. Because we do not have data on mortgage refinancing for all the years in the sample, we are unable to explore the relationship between house prices and consumption supported by mortgage refinancing. 


\section{Alternative Specifications}

Table D1: Total Debt Quantile Regression Results (with House Price Growth)

\begin{tabular}{|c|c|c|c|c|c|c|}
\hline & 0.1 & 0.25 & $\begin{array}{c}\text { Quantile } \\
0.5\end{array}$ & 0.75 & 0.9 & Mean \\
\hline House Price Growth & $\begin{array}{l}-0.198 \\
(0.16)\end{array}$ & $\begin{array}{c}-0.248^{* *} \\
(0.09)\end{array}$ & $\begin{array}{c}-0.152^{* *} \\
(0.05)\end{array}$ & $\begin{array}{l}-0.069 \\
(0.04)\end{array}$ & $\begin{array}{c}-0.128^{* * *} \\
(0.04)\end{array}$ & $\begin{array}{c}-0.171^{* *} \\
(0.07)\end{array}$ \\
\hline Homeowner & $\begin{array}{c}3.584^{* * *} \\
(0.23)\end{array}$ & $\begin{array}{c}2.323^{* * *} \\
(0.13)\end{array}$ & $\begin{array}{c}1.702^{* * *} \\
(0.07)\end{array}$ & $\begin{array}{c}1.420^{* * *} \\
(0.05)\end{array}$ & $\begin{array}{c}1.362^{* * *} \\
(0.05)\end{array}$ & $\begin{array}{c}1.813^{* * *} \\
(0.02)\end{array}$ \\
\hline Interest Rate & $\begin{array}{c}-0.064^{*} \\
(0.03)\end{array}$ & $\begin{array}{c}-0.040^{*} \\
(0.02)\end{array}$ & $\begin{array}{c}-0.026^{* *} \\
(0.01)\end{array}$ & $\begin{array}{c}-0.019^{* *} \\
(0.01)\end{array}$ & $\begin{array}{l}-0.009 \\
(0.01)\end{array}$ & $\begin{array}{c}-0.038^{*} \\
(0.02)\end{array}$ \\
\hline Income 1 & $\begin{array}{c}2.194^{* * *} \\
(0.17)\end{array}$ & $\begin{array}{c}0.944^{* * *} \\
(0.10)\end{array}$ & $\begin{array}{c}0.406^{* * *} \\
(0.05)\end{array}$ & $\begin{array}{c}0.271^{* * *} \\
(0.04)\end{array}$ & $\begin{array}{c}0.263^{* * *} \\
(0.04)\end{array}$ & $\begin{array}{c}0.684^{* * *} \\
(0.02)\end{array}$ \\
\hline Income 2 & $\begin{array}{c}2.492^{* * *} \\
(0.17)\end{array}$ & $\begin{array}{c}1.260^{* * *} \\
(0.10)\end{array}$ & $\begin{array}{c}0.700^{* * *} \\
(0.05)\end{array}$ & $\begin{array}{c}0.530^{* * *} \\
(0.04)\end{array}$ & $\begin{array}{c}0.545^{* * *} \\
(0.04)\end{array}$ & $\begin{array}{c}0.997^{* * *} \\
(0.03)\end{array}$ \\
\hline Income 3 & $\begin{array}{c}1.774^{* * *} \\
(0.12)\end{array}$ & $\begin{array}{c}1.218^{* * *} \\
(0.07)\end{array}$ & $\begin{array}{c}0.972^{* * *} \\
(0.04)\end{array}$ & $\begin{array}{c}0.905^{* * *} \\
(0.03)\end{array}$ & $\begin{array}{c}0.895^{* * *} \\
(0.03)\end{array}$ & $\begin{array}{c}1.085^{* * *} \\
(0.04)\end{array}$ \\
\hline Age & $\begin{array}{c}0.475^{* * *} \\
(0.07)\end{array}$ & $\begin{array}{c}0.120^{* *} \\
(0.04)\end{array}$ & $\begin{array}{l}0.013 \\
(0.02)\end{array}$ & $\begin{array}{c}-0.049^{* *} \\
(0.02)\end{array}$ & $\begin{array}{c}-0.037^{*} \\
(0.02)\end{array}$ & $\begin{array}{c}0.107^{* * *} \\
(0.03)\end{array}$ \\
\hline $\mathrm{Age}^{2}$ & $\begin{array}{c}-0.010^{* * *} \\
(0.00)\end{array}$ & $\begin{array}{c}-0.002^{* *} \\
(0.00)\end{array}$ & $\begin{array}{r}-0.000 \\
(0.00)\end{array}$ & $\begin{array}{c}0.001^{* * *} \\
(0.00)\end{array}$ & $\begin{array}{c}0.001^{*} \\
(0.00)\end{array}$ & $\begin{array}{c}-0.002^{* * *} \\
(0.00)\end{array}$ \\
\hline $\operatorname{Age}^{3}$ & $\begin{array}{c}0.000^{* * *} \\
(0.00)\end{array}$ & $\begin{array}{l}0.000 \\
(0.00)\end{array}$ & $\begin{array}{r}-0.000 \\
(0.00)\end{array}$ & $\begin{array}{c}-0.000^{* * *} \\
(0.00)\end{array}$ & $\begin{array}{c}-0.000^{* *} \\
(0.00)\end{array}$ & $\begin{array}{c}0.000 * * * \\
(0.00)\end{array}$ \\
\hline Education (High School) & $\begin{array}{c}0.380^{* * *} \\
(0.06)\end{array}$ & $\begin{array}{c}0.123^{* * *} \\
(0.04)\end{array}$ & $\begin{array}{c}0.043^{*} \\
(0.02)\end{array}$ & $\begin{array}{c}-0.019 \\
(0.02)\end{array}$ & $\begin{array}{l}-0.006 \\
(0.02)\end{array}$ & $\begin{array}{c}0.107^{* * *} \\
(0.02)\end{array}$ \\
\hline Education (University) & $\begin{array}{l}0.057 \\
(0.05)\end{array}$ & $\begin{array}{c}0.140^{* * *} \\
(0.03)\end{array}$ & $\begin{array}{c}0.162^{* * *} \\
(0.01)\end{array}$ & $\begin{array}{c}0.158^{* * *} \\
(0.01)\end{array}$ & $\begin{array}{c}0.152^{* * *} \\
(0.01)\end{array}$ & $\begin{array}{c}0.142^{* * *} \\
(0.02)\end{array}$ \\
\hline Business Owner & $\begin{array}{c}0.577^{* * *} \\
(0.07)\end{array}$ & $\begin{array}{c}0.174^{* * *} \\
(0.04)\end{array}$ & $\begin{array}{c}0.092^{* * *} \\
(0.02)\end{array}$ & $\begin{array}{c}0.094^{* * *} \\
(0.02)\end{array}$ & $\begin{array}{c}0.134^{* * *} \\
(0.02)\end{array}$ & $\begin{array}{c}0.229 * * * \\
(0.02)\end{array}$ \\
\hline Adults & $\begin{array}{c}0.172^{* * *} \\
(0.03)\end{array}$ & $\begin{array}{l}0.016 \\
(0.02)\end{array}$ & $\begin{array}{r}-0.006 \\
(0.01)\end{array}$ & $\begin{array}{l}0.000 \\
(0.01)\end{array}$ & $\begin{array}{c}0.025^{* * *} \\
(0.01)\end{array}$ & $\begin{array}{c}0.035^{* * *} \\
(0.01)\end{array}$ \\
\hline Labour Productivity & $\begin{array}{l}0.338 \\
(0.19)\end{array}$ & $\begin{array}{c}0.571^{* * *} \\
(0.11)\end{array}$ & $\begin{array}{c}0.669^{* * *} \\
(0.06)\end{array}$ & $\begin{array}{c}0.582^{* * *} \\
(0.05)\end{array}$ & $\begin{array}{c}0.467^{* * *} \\
(0.05)\end{array}$ & $\begin{array}{c}0.502^{* * *} \\
(0.08)\end{array}$ \\
\hline Unemployment & $\begin{array}{l}-0.008 \\
(0.01)\end{array}$ & $\begin{array}{c}-0.034^{* * *} \\
(0.01)\end{array}$ & $\begin{array}{c}-0.038^{* * *} \\
(0.00)\end{array}$ & $\begin{array}{c}-0.036^{* * *} \\
(0.00)\end{array}$ & $\begin{array}{c}-0.037^{* * *} \\
(0.00)\end{array}$ & $\begin{array}{c}-0.029^{* * *} \\
(0.00)\end{array}$ \\
\hline Constant & $\begin{array}{c}-4.209^{* *} \\
(1.48)\end{array}$ & $\begin{array}{c}4.497^{* * *} \\
(0.84)\end{array}$ & $\begin{array}{c}7.371^{* * *} \\
(0.45)\end{array}$ & $\begin{array}{c}9.192^{* * *} \\
(0.38)\end{array}$ & $\begin{array}{c}9.623^{* * *} \\
(0.36)\end{array}$ & $\begin{array}{c}5.524^{* * *} \\
(0.48)\end{array}$ \\
\hline (Pseudo) $\mathrm{R}^{2}$ & $(0.232)$ & $(0.273)$ & $(0.299)$ & $(0.267)$ & $(0.237)$ & \\
\hline Obs. & 105,544 & 105,544 & 105,544 & 105,544 & 105,544 & 105,544 \\
\hline Uncensored Obs. & 73,830 & 73,830 & 73,830 & 73,830 & 73,830 & 73,830 \\
\hline
\end{tabular}

Note: House prices and regional labour productivity are in logs. House price growth is the log of house regional house prices at time $t$ minus the log of house prices at $t-4$. Income 1 is a dummy variable for those households whose income the previous year was between $\$ 35,000$ and $\$ 49,999$. Income 2 is a dummy for those with incomes between $\$ 50,000$ and $\$ 99,999$, and Income 3 is a dummy for those with incomes exceeding $\$ 100,000$. The reference group for income are those households who earned less than $\$ 35,000$ in the previous year. Education (High School) is a dummy for those who have a high school diploma, and Education (University) is a dummy for those who have a university degree. The reference group for education are those who have not completed high school. Each specification includes quarterly time dummies, month dummies, and age cohort dummies. Both the quantile and mean regressions account for selection (only those with positive debt are included in the outcome regressions) and the reported point estimates are unadjusted, meaning they apply only to those with positive debt. .

*** Significant at the $1 \%$ level; ** significant at the $5 \%$ level; * significant at the $10 \%$ level. 
Table D2: Non-Mortgage Debt Regression Results (with House Price Growth)

\begin{tabular}{|c|c|c|c|c|}
\hline & I & II & III & IV \\
\hline Interest Rate & $\begin{array}{l}-0.029 \\
(0.02)\end{array}$ & $\begin{array}{l}-0.030 \\
(0.02)\end{array}$ & $\begin{array}{l}-0.030 \\
(0.02)\end{array}$ & $\begin{array}{l}-0.029 \\
(0.02)\end{array}$ \\
\hline Income 1 & $\begin{array}{l}0.037 \\
(0.03)\end{array}$ & $\begin{array}{l}0.030 \\
(0.03)\end{array}$ & $\begin{array}{l}0.030 \\
(0.03)\end{array}$ & $\begin{array}{l}0.033 \\
(0.03)\end{array}$ \\
\hline Income 2 & $\begin{array}{c}0.333^{* * *} \\
(0.04)\end{array}$ & $\begin{array}{c}0.323^{* * *} \\
(0.04)\end{array}$ & $\begin{array}{c}0.323^{* * *} \\
(0.04)\end{array}$ & $\begin{array}{c}0.323^{* * *} \\
(0.04)\end{array}$ \\
\hline Income 3 & $\begin{array}{c}0.770^{* * *} \\
(0.06)\end{array}$ & $\begin{array}{c}0.758^{* * *} \\
(0.06)\end{array}$ & $\begin{array}{c}0.758^{* * *} \\
(0.06)\end{array}$ & $\begin{array}{c}0.756^{* * *} \\
(0.06)\end{array}$ \\
\hline Age & $\begin{array}{l}-0.036 \\
(0.03)\end{array}$ & $\begin{array}{c}-0.043 \\
(0.03)\end{array}$ & $\begin{array}{l}-0.043 \\
(0.03)\end{array}$ & $\begin{array}{c}-0.069^{*} \\
(0.03)\end{array}$ \\
\hline $\mathrm{Age}^{2}$ & $\begin{array}{l}0.001 \\
(0.00)\end{array}$ & $\begin{array}{l}0.001 \\
(0.00)\end{array}$ & $\begin{array}{l}0.001 \\
(0.00)\end{array}$ & $\begin{array}{c}0.002^{*} \\
(0.00)\end{array}$ \\
\hline $\mathrm{Age}^{3}$ & $\begin{array}{r}-0.000 \\
(0.00)\end{array}$ & $\begin{array}{r}-0.000 \\
(0.00)\end{array}$ & $\begin{array}{l}-0.000 \\
(0.00)\end{array}$ & $\begin{array}{c}-0.000^{*} \\
(0.00)\end{array}$ \\
\hline Education (High School) & $\begin{array}{c}-0.055^{*} \\
(0.03)\end{array}$ & $\begin{array}{l}-0.052 \\
(0.03)\end{array}$ & $\begin{array}{l}-0.052 \\
(0.03)\end{array}$ & $\begin{array}{c}-0.054^{*} \\
(0.03)\end{array}$ \\
\hline Education (University) & $\begin{array}{c}0.113^{* * *} \\
(0.02)\end{array}$ & $\begin{array}{c}0.117^{* * *} \\
(0.02)\end{array}$ & $\begin{array}{c}0.117^{* * *} \\
(0.02)\end{array}$ & $\begin{array}{c}0.117^{* * *} \\
(0.02)\end{array}$ \\
\hline Business Owner & $\begin{array}{c}0.085^{* *} \\
(0.03)\end{array}$ & $\begin{array}{c}0.082^{* *} \\
(0.03)\end{array}$ & $\begin{array}{c}0.082^{* *} \\
(0.03)\end{array}$ & $\begin{array}{c}0.083^{* *} \\
(0.03)\end{array}$ \\
\hline Adults & $\begin{array}{l}-0.008 \\
(0.01)\end{array}$ & $\begin{array}{l}-0.012 \\
(0.01)\end{array}$ & $\begin{array}{l}-0.012 \\
(0.01)\end{array}$ & $\begin{array}{l}-0.013 \\
(0.01)\end{array}$ \\
\hline Labour Productivity & $\begin{array}{c}0.422^{* * *} \\
(0.11)\end{array}$ & $\begin{array}{c}0.419^{* * *} \\
(0.11)\end{array}$ & $\begin{array}{c}0.419^{* * *} \\
(0.11)\end{array}$ & $\begin{array}{c}0.419^{* * *} \\
(0.11)\end{array}$ \\
\hline Unemployment & $\begin{array}{c}-0.036^{* * *} \\
(0.01)\end{array}$ & $\begin{array}{c}-0.036^{* * *} \\
(0.01)\end{array}$ & $\begin{array}{c}-0.036^{* * *} \\
(0.01)\end{array}$ & $\begin{array}{c}-0.036^{* * *} \\
(0.01)\end{array}$ \\
\hline House Price Growth & $\begin{array}{l}-0.027 \\
(0.08)\end{array}$ & $\begin{array}{c}-0.025 \\
(0.08)\end{array}$ & $\begin{array}{c}-0.061 \\
(0.16)\end{array}$ & $\begin{array}{l}-0.101 \\
(0.25)\end{array}$ \\
\hline Homeowner & & $\begin{array}{c}0.063^{*} \\
(0.03)\end{array}$ & $\begin{array}{c}0.060^{*} \\
(0.03)\end{array}$ & $\begin{array}{l}0.000 \\
(0.04)\end{array}$ \\
\hline House Price Growth $*$ Homeowner & & & $\begin{array}{l}0.048 \\
(0.17)\end{array}$ & \\
\hline Constant & $\begin{array}{c}9.082^{* * *} \\
(0.59)\end{array}$ & $\begin{array}{c}9.297^{* * *} \\
(0.58)\end{array}$ & $\begin{array}{c}9.297^{* * *} \\
(0.58)\end{array}$ & $\begin{array}{c}9.692^{* * *} \\
(0.61)\end{array}$ \\
\hline \multicolumn{5}{|c|}{ Combined effects of house prices on homeowners of different age groups } \\
\hline Age $18-35$ & & & & $0.276^{* *}$ \\
\hline Age $36-55$ & & & & -0.091 \\
\hline Age $56+$ & & & & -0.162 \\
\hline $\begin{array}{l}\text { Obs. } \\
\text { Uncensored Obs. }\end{array}$ & $\begin{array}{l}105,544 \\
52,585\end{array}$ & $\begin{array}{l}105,544 \\
52,585\end{array}$ & $\begin{array}{l}105,544 \\
52,585\end{array}$ & $\begin{array}{l}105,544 \\
52,585\end{array}$ \\
\hline
\end{tabular}

Note: Income 1 is a dummy variable for those households whose income the previous year was between $\$ 35,000$ and $\$ 49,999$. Income 2 is a dummy for those with incomes between $\$ 50,000$ and $\$ 99,999$, and Income 3 is a dummy for those with incomes exceeding $\$ 100,000$. The reference group for income are those households who earned less than $\$ 35,000$ in the previous year. Education (High School) is a dummy for those who have a high school diploma, and Education (University) is a dummy for those who have a university degree. Each specification includes quarterly time dummies, month dummies, and age cohort dummies. The errors are clustered at the forward sortation area level (this is based on the first three digits of the area code - there are 1614 forward sortation areas). The mean regressions account for selection (only those with positive non-mortgage debt are included in the outcome regressions) and the reported point estimates are unadjusted, meaning they apply only to those with positive non-mortgage debt.

*** Significant at the $1 \%$ level; ${ }^{* *}$ significant at the $5 \%$ level; * significant at the $10 \%$ level. 